\title{
LIFE HISTORY PATTERNS OF MODERN AND FOSSIL MERCENARIA SPP. FROM WARM VS. COLD CLIMATES
}

\author{
Kylie L. Palmer
}

A thesis submitted to the faculty at the University of North Carolina at Chapel Hill in partial fulfillment of the requirements for the degree of Master of Science in the Department of Geology.

\section{Chapel Hill}

2020

Approved by:

Donna Surge

David K. Moss

Joseph G. Carter 
(C)2020

Kylie L. Palmer

ALL RIGHTS RESERVED 


\begin{abstract}
Kylie Palmer: Life history patterns of modern and fossil Mercenaria spp. from warm vs. cold climates

(Under the direction of Donna Surge)
\end{abstract}

Recent work projects significant increases in sea surface temperature over the next century. The biological consequences of such change are poorly understood. Study designs using conservation paleobiology combined with sclerochronology can provide a framework to assess these consequences. This study focuses on fossil Mercenaria spp. that grew during climates warmer/comparable to today. We compared lifespans and growth rates of modern Mercenaria spp. populations to those from the mid Pliocene and early Pleistocene to better understand the influences of temperature on life history. We found that growth rates tend to increase with increasing temperature both through space and time. However, the relationship between lifespan and temperature is unclear. Further, we observe that mid-high latitude individuals seem to be more impacted by changes in temperature than low latitude individuals. These findings provide insight to how Mercenaria might respond to future projected environmental change. 


\section{ACKNOWLEDGEMENTS}

I thank my advisor, Donna Surge, for her guidance during this process. I also thank my committee member, David Moss, for sharing his time and knowledge and consistently being a positive reinforcement. In addition, thanks to Joe Carter for his guidance and feedback on this project. Without the help of my committee members, this work would not be possible. Further, I thank Roger Portell and John Slapcinsky from the Florida Museum of Natural History and Trish Weaver from the North Carolina Museum of Natural Sciences for loaning specimens for destructive analysis. Thanks to Emily Michael and Sage Turek for assisting in shell preparation and analysis. Thanks to John Robeson for access to his property for fossil collection. Thanks to Troy Alpine, Bob Simmons, and Gerry Brett Sr. for assistance with field collections. Additionally, thanks to Erika Kruger and Sarina Little for their support, encouragement and providing feedback on writing.

This work was supported by the United States National Science Foundation (grant \#EAR1656974; awarded to DS), the Preston Jones and Mary Elizabeth Frances Dean Martin Fellowship Fund at the University of North Carolina at Chapel Hill, Department of Geological Sciences; and the Paleontological Society of America and Conchologist of America graduate student research grants.

Finally, I thank my Mom and Dad and friends and family for their endless support and encouragement. 


\section{TABLE OF CONTENTS}

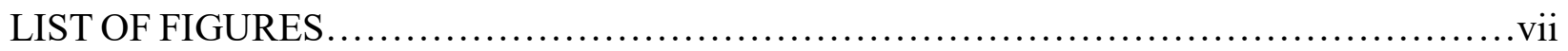

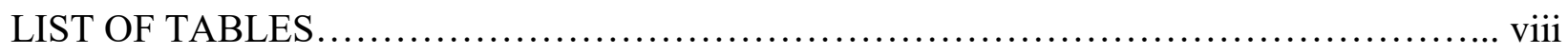

LIST OF ABBREVIATIONS AND SYMBOLS ..................................... ix

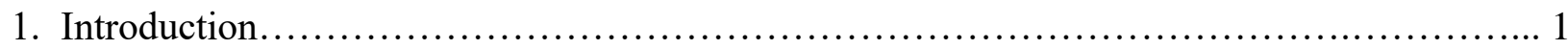

2. Geologic Context............................................................ 2

2.1 Collection sites.......................................................... 2

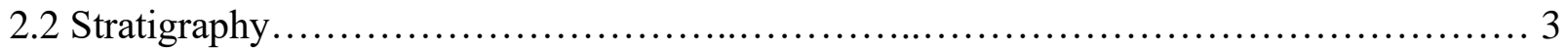

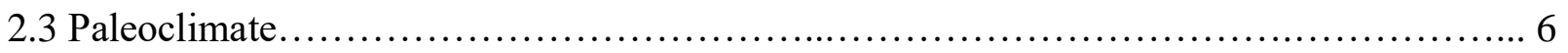

3. Biogeography and ecology of Mercenaria...................................... 7

4. Mercenaria species identification................................................ 8

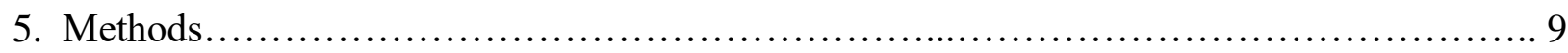

5.1 North Carolina fossil Mercenaria identification................................. 9

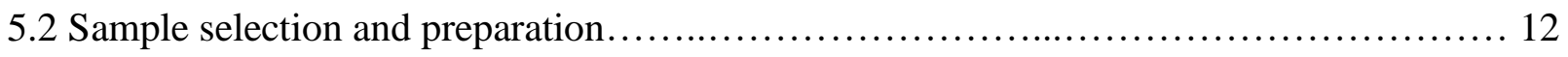

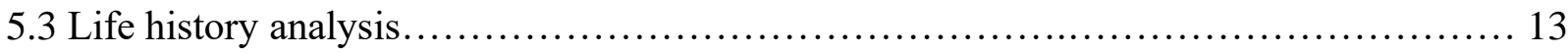

6. Results.................................................................. 14

6.1 Life history of $M$. campechiensis and $M$. permagna............................. 14

6.2 Population-level lifespan and growth rates.................................... 15

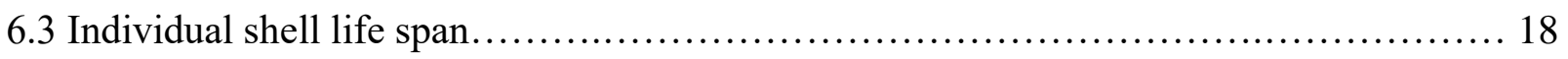

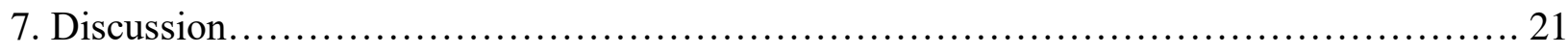

7.1 Fossil Mercenaria life history: space and time................................ 21 


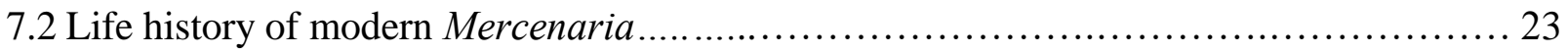

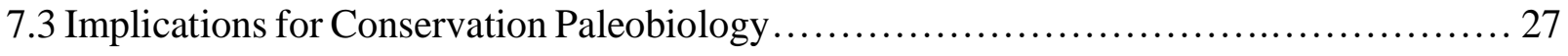

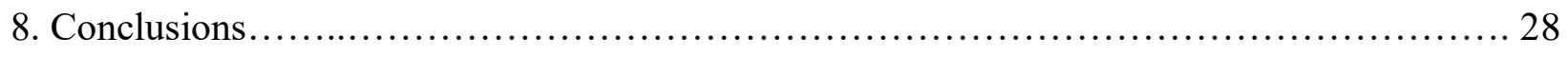

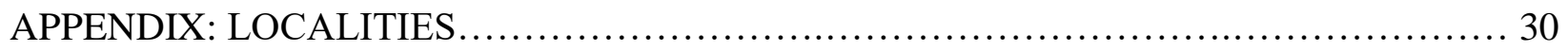

APPENDIX: VON BERTALANFFY R CODE DOCUMENTATION ......................... 31

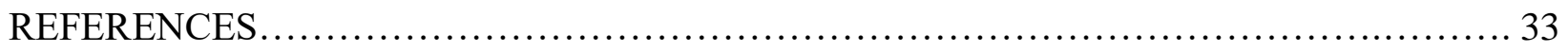




\section{LIST OF FIGURES}

Figure 1. Map and stratigraphy of study regions..................................... 4

Figure 2. Mercenaria species comparison......................................... 11

Figure 3. Mercenaria thick section and growth increments............................. 13

Figure 4. Mercenaria species von Bertalanffy growth curves.......................... 15

Figure 5. Modern and fossil von Bertalanffy growth curves .............................. 17

Figure 6. Individual lifespan box plot......................................... 19

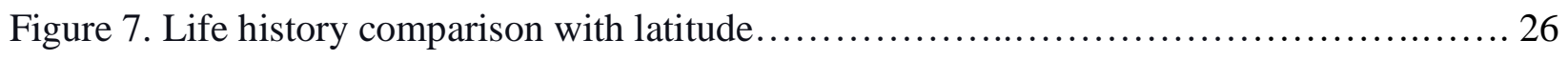

Appendix Figure 1. Modern and fossil locality details................................ 30 


\section{LIST OF TABLES}

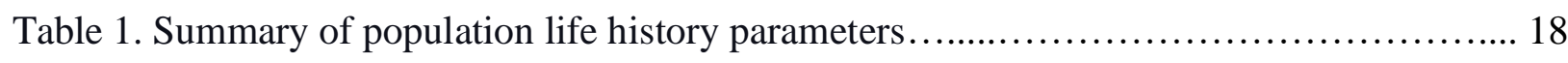

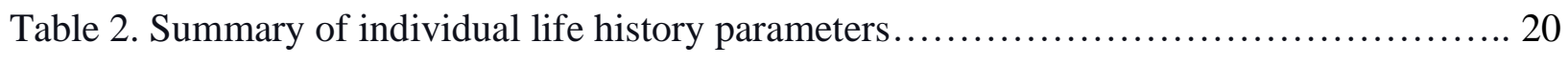

Table 3. Tukey Honestly Significant Difference test results .......................... 20 


\section{LIST OF ABBREVIATIONS AND SYMBOLS}

$\sigma$

$\pm$

${ }^{\circ} \mathrm{C}$

CAL

DUP

et al.

GCP

i.e.,

IPCC

$\mathrm{k}$

$\mathrm{Lt}$

$\mathrm{L}_{\infty}$

LSP

M. campechiensis

M. mercenaria

M. permagna

$\mathrm{Ma}$

MACP

MAX

MIN

MLSP

MPWP standard deviation

plus or minus

degrees Celsius

Caloosahatchee Formation

Duplin Formation

and others

Gulf Coastal Plain

that is

Intergovernmental Panel on Climate Change

growth appromiation

shell length at time $t$

asymptotic size

lifespan

Mercenaria campechiensis

Mercenaria mercenaria

Mercenaria permagna

megaannum

Mid Atlantic Coastal Plain

maximum

minimum

maximum life span

Mid Pliocene Warm Period 


$\begin{array}{ll}\text { nshells } & \begin{array}{l}\text { number of shells } \\ \text { PINE }\end{array} \\ \text { psu } & \text { Pinecrest Formation } \\ \text { SANC } & \text { modern North Carolina } \\ \text { SFL } & \text { modern Florida } \\ \text { t } & \text { time } \\ \text { to } & \text { initial organism length } \\ \text { UNCW } & \text { University of North Carolina at Wilmington } \\ \text { VBG } & \text { von Bertalanffy growth equation } \\ \text { WAC } & \text { Lower Waccamaw Formation }\end{array}$




\section{LIFE HISTORY PATTERNS OF MODERN AND FOSSIL MERCENARIA SPP. FROM WARM VS. COLD CLIMATE}

\section{Introduction}

Future warming projected by the Intergovernmental Panel on Climate Change (IPCC) estimates a $0.3-4.8^{\circ} \mathrm{C}$ increase in global mean surface temperature by the end of the 21 st century (Collins et al., 2013). Such changes pose significant socioeconomic stresses given potential extreme weather events, rising sea-level, and migrating ecosystems and resources (Robinson et al., 2008). One way to understand the impacts of climate change on marine ecosystems, in particular, is through conservation paleobiology. This field of research uses geohistorical analysis to understand species response to changing climate (Dowsett et al., 2009; Dietl and Flessa, 2011). Such knowledge is critical in acquiring a long-term perspective on modern ecosystems and to develop more effective tools for conserving and restoring biodiversity and ecosystems in the face of an uncertain future (Dowsett et al., 2009; Dietl and Flessa, 2011; Dietl et al., 2015).

Sclerochronology, the study of periodic growth structures in the skeletal portions of organisms that grow by accretion (Buddemeier et al., 1974; Jones, 1988), is a powerful tool used in conservation paleobiology. Bivalves are one of the major groups in a wide range of organisms studied using sclerochronology (Surge and Schöne, 2015). Like tree rings, growth increments in bivalves act as skeletal diaries preserving life history patterns and records of environmental change. As some of the longest-lived non-colonial organisms on the planet today (e.g., Schöne et al., 2005; Ridgway and Richardson, 2011; Butler et al., 2013), bivalves are ideal targets for 
paleoclimate and sclerochronology research. In addition to their exceptional longevity, modern bivalve species exhibit a latitudinal pattern relative to their life history. Individuals from low latitudes tend to have faster growth rates and shorter lifespans compared to those from mid-high latitudes, suggesting environmental conditions (e.g., food availability, water temperatures, ect.) influence longevity (Moss et al., 2016, 2017; Saulsbury et al., 2019). Under the premise that water temperature is an important factor in determining life history, here, we ask how do lifespans and growth rates of bivalves change during warm and cold climate conditions?

We compare mid Pliocene, early Pleistocene, and modern Mercenaria spp. shells from the Mid-Atlantic Coastal Plain (MACP) and Gulf Coastal Plain (GCP) of the United States to establish the relationship between lifespan and growth rate across spatial and temporal scales from different climate states. We test the following hypotheses: (1) latitudinal life history gradients exist in fossil and modern Mercenaria spp. irrespective of climatic setting, and (2) warmer climates (mid Pliocene) will have faster growth rates and shorter lifespans compared to those from colder climates (early Pleistocene). Establishing the relationship between lifespan and growth rate during climate conditions warmer than today will provide us with a deeper understanding of marine bivalves' potential response to future environmental change. Understanding these responses will provide insight for future management of the marine ecosystems in which they inhabit.

\section{Geologic context and material}

\subsection{Collection sites}

Fossil Mercenaria spp. shells were collected from MPWP (Duplin Formation, NC; Pinecrest Beds, FL), early Pleistocene (Lower Waccamaw Formation, NC; Caloosahatchee, FL), and modern localities in North Carolina and Florida (Figure. 1A) to investigate life history 
patterns through space and time (see Appendix Figure. 1 for latitude and longitude). Duplin Formation shells were collected from the Robeson Farm locality southwest of the Cape Fear River, approximately $2 \mathrm{~km}$ east-southeast of Tar Heel, North Carolina. As described by Britt et al. (1992), this locality includes a ravine exposure, a smaller overlying slump exposure, and a gully exposure. These exposures contain several meters of mid Pliocene clastic open-marine to nearshore sediments. Shells from the Lower Waccamaw Formation were collected from the Register Quarry locality in Columbus County, North Carolina. This exposure consists of mollusc-rich, fine to coarse sand. Bivalves are generally convex upward with some rough bedding orientation, and some bivalves are still articulated (Ward et al., 1991). Modern North Carolina shells were collected alive in approximately 1 meter water depth from the University of North Carolina at Wilmington's (UNCW) marine sanctuary, Wilmington, North Carolina. The Florida Museum of Natural History provided shells from the Pinecrest, Caloosahatchee, and modern setting in Florida (see Appendix Figure. 1 for locality details).

\subsection{Stratigraphy}

Previous studies extensively describe the Plio-Pleistocene stratigraphy within the MACP and GCP (Gardner, 1943; Ward, 1980; Ward and Blackwelder, 1987; Krantz, 1991). Within these sequences, the early Pleistocene Lower Waccamaw and Caloosahatchee Formations unconformably overlie the mid Pliocene Duplin Formation and Pinecrest Beds Member of the Tamiami Formation in North Carolina and Florida, respectively (Figure. 1B) (Hazel, 1977; Ward and Blackwelder, 1980, 1987; Cronin, 1988; Jones et al., 1991; Willard et al.,1993). These deposits are known for their abundant and pristine preservation of marine fauna, including the bivalve genus Mercenaria. 

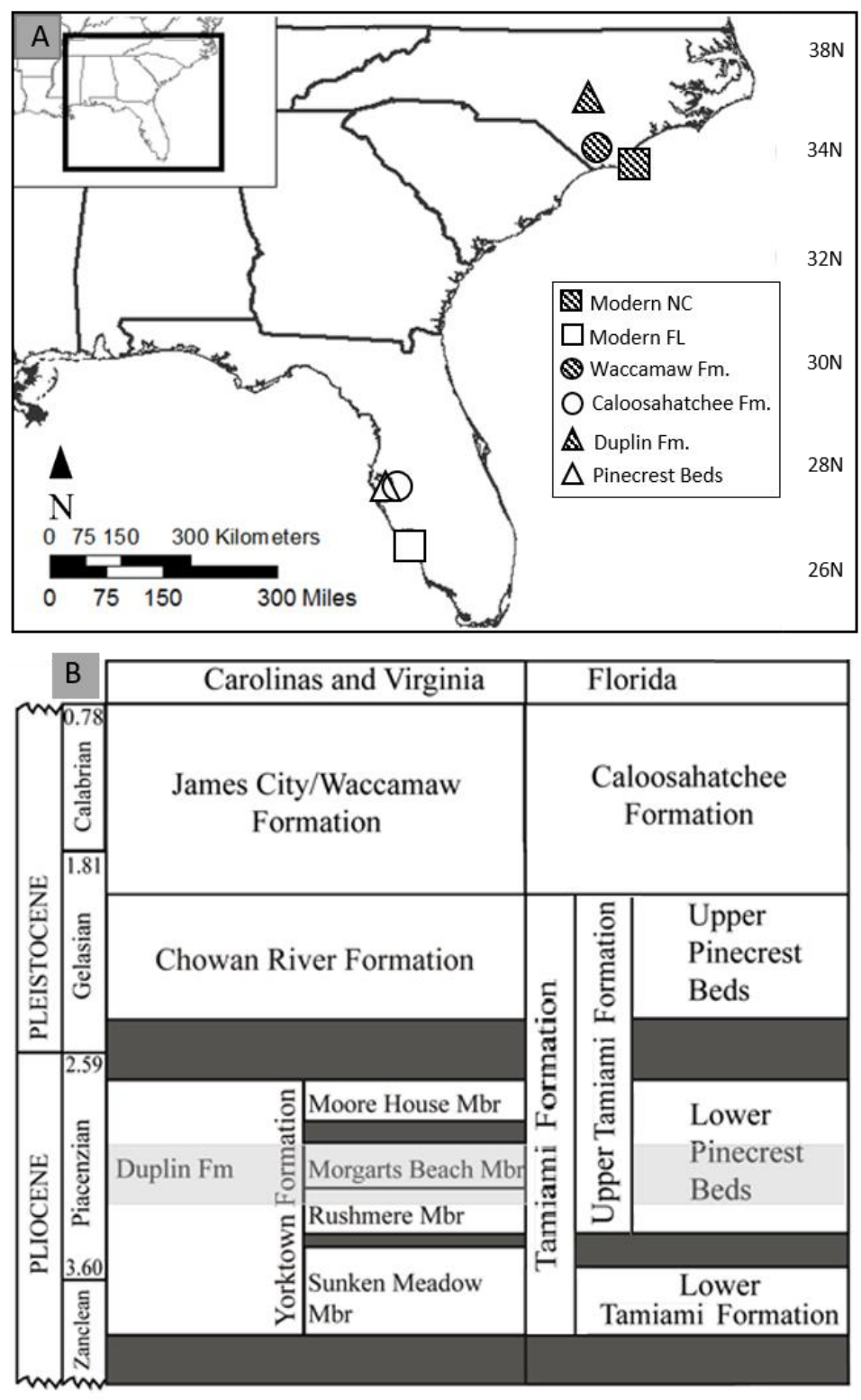

Figure. 1. A) Collection sites along the Mid-Atlantic and Gulf Coastal Plains. Trian-

gles=MPWP, circles=early Pleistocene, and squares=modern localities. B) Plio-Pleistocene stratigraphy of the MACP and GCP. Gray box indicates the MPWP. See Appendix Figure. 1 for locality details.

The Pinecrest Beds are stratigraphically equivalent to the Duplin Formation (Olsson and Petit, 1964; Hazel, 1977; Gibson, 1983, 1987; Cronin, 1988; Jones et al., 1991; Krantz, 1991; Allmon, 1993). Faunal assemblages indicate the Pinecrest Beds ( 3.5-2.5 Ma) and the Duplin 
Formation ( 3.5-2.4 Ma) were deposited in a transgression event during the MPWP (Hazel, 1977; Gibson, 1983, 1987; Cronin, 1988; Jones et al., 1991; Allmon, 1993; Willard et al., 1993; Missimer, 2001). Deposition of the Pinecrest Beds and Duplin Formations occurred over a period of approximately one million years (Hazel, 1977; Gibson, 1983, 1987; Cronin, 1988; Jones et al., 1991; Allmon, 1993; Willard et al., 1993; Missimer, 2001). Ostracod and foraminifer records of the Pinecrest Beds indicate warm-temperature conditions deposited in offshore, mid-shelf, normal marine conditions (Willard et al., 1993; Jones and Allmon, 1995). Molluscan fauna analysis of the Duplin Formation is also indicative of warm-temperate conditions deposited in shallow, warm marine, inner to middle shelf conditions (Richards, 1967; Ottens et al., 2012).

The Caloosahatchee and Lower Waccamaw Formations are stratigraphically equivalent units deposited in a transgressive event during the Gelasian Stage of the early Pleistocene (Olsson and Petit, 1964; Gibson, 1987, 1983; Cronin, 1988; Jones et al., 1991; Krantz, 1991; Allmon, 1993). Biostratigraphy provides age constraints for the Caloosahatchee ( 1.8-2.5 Ma) and the Lower Waccamaw ( 1.8-2.1 Ma) Formations, both representing less than one million years of deposition (Bender, 1973; Hazel, 1977; Ward and Blackwelder, 1980, 1987; Cronin, 1988; Jones et al., 1991; Willard et al., 1993). Molluscan assemblages of the Caloosahatchee Formation suggest warm-temperate conditions (Lloyd, 1969; Willard et al., 1993; Missimer, 2001). Several researchers assigned a warm-temperate designation to the Lower Waccamaw Formation (Blackwelder, 1981; Gibson, 1983, 1987; Krantz, 1990). However, winter temperatures estimates based on isotopic data fall below $12^{\circ} \mathrm{C}$ (Krantz, 1990) indicative of coldtemperate conditions as defined by Briggs (1995) and Briggs and Bowen (2012). Thus, we redefine the Lower Waccamaw Formation as cold temperate. Both the Caloosahatchee and 
Duplin Formations generally represent shallow, marine conditions (Lloyd, 1969;

Blackwelder, 1981; Krantz, 1991; Willard et al., 1993; Missimer, 2001).

\subsection{Paleoclimate context}

Paleoclimate reconstructions of the MPWP and the Gelasian stage of the early

Pleistocene are based on proxy data and general circulation models (e.g., Raymo et al., 1996;

Sloan et al., 1996; Lisiecki and Raymo, 2005; Dowsett, 2007; Robinson et al., 2008; Scherer et al., 2008; Dowsett et al., 2009; Chan et al., 2011; Winkelstern et al., 2013; Zhang et al., 2013; Johnson et al., 2017). Reduced global ice volume and increased global warmth characterize the MPWP (Dowsett and Cronin, 1990; Krantz, 1990). Previous studies link the MPWP along the MACP and GCP with increases in meridional heat transport as a result of the shoaling and closure of the Isthmus of Panama (Keigwin, 1978, 1982; Maier-Reimer et al., 1990; Missimer, 2001; Brierley et al., 2009; Dowsett and Robinson, 2009). Paleoclimate reconstruction of the MPWP Duplin Formation and Pinecrest Beds suggest annual temperatures ranges of $13-24^{\circ} \mathrm{C}$ and $15-25^{\circ} \mathrm{C}$, respectively, during the time of deposition (Dowsett and Cronin, 1990; Cronin, 1991; Willard et al., 1993; Cronin and Dowsett, 1996). Winkelstern et al. (2013) reconstructed shallow seawater temperature using oxygen isotope ratios of fossil Mercenaria spp. from the Rushmere Member of the Yorktown Formation in Virginia, which is equivalent to the Duplin Formation and Pinecrest Beds. Their study reports mid-latitude sea surface temperature during the winter months was $17 \pm 2^{\circ} \mathrm{C}$ and the summer temperature was $25 \pm 2^{\circ} \mathrm{C}$.

Following mid Pliocene warming, subsequent global cooling trends dominated the early Pleistocene Gelasian stage (Lisiecki and Raymo, 2005). Alternations of glacial and interglacial cycles controlled by obliquity oscillations characterize this time interval (Ruddiman et al., 1986; Raymo et al., 1989; Lisiecki and Raymo, 2005). Individual interglacial periods of the Gelasian 
stage correspond to climate conditions comparable to or warmer than today (Mercer, 1978;

Krantz, 1990; Lisiecki and Raymo, 2005). Paleoclimate reconstructions of the Caloosahatchee and Lower Waccamaw Formations suggest annual temperature ranges of $16-25^{\circ} \mathrm{C}$ and $6-21^{\circ} \mathrm{C}$, respectively (Krantz, 1990; Willard et al., 1993; Cronin and Dowsett, 1996; Tao et al., 2012). Winkelstern et al. (2013) report coldest winter temperatures $\left(12 \pm 2^{\circ} \mathrm{C}\right)$ and warmest summer temperatures $\left(21 \pm 2^{\circ} \mathrm{C}\right)$ from the early Pleistocene Chowan River Formation in Virginia, equivalent in depositional timing to the Lower Waccamaw and Caloosahatchee Formations.

\section{Biogeography and ecology of Mercenaria}

Mercenaria species are infaunal suspension feeders commonly found within estuaries, tidal flats, and offshore environments (Jorgensen, 1975; Peterson et al., 1984; Grizzle et al., 2001). They are shallow burrowers, burrowing approximately $4 \mathrm{~cm}$ beneath the surface (Ansell, 1962). Mercenaria can survive in water temperatures between 9 and $31^{\circ} \mathrm{C}$ (Ansell, 1968). The most rapid growth of Mercenaria occurs in salinities between 20 and 30 psu (practical salinity units) and temperatures between 15 and $25^{\circ} \mathrm{C}$ (Ansell, 1968). Spawning takes place in favorable temperature ranges unique to their biogeographic region. For example, in Core Sound, NC spawning is typically when water temperatures are between $27-30^{\circ} \mathrm{C}$ (Peterson and Fegley, 1986), whereas in Alligator Harbor, FL, it is between $16-20^{\circ} \mathrm{C}$ (Hesselman et al., 1989). They reach sexual maturity at a minimum shell length of 20-35 mm (Belding, 1930; Loosanoff, 1937; Hesselman et al., 1988; Walker and Heffernan, 1995). The age of sexual maturity varies with biogeographic region. For example, M. mercenaria from the Gulf of St. Lawrence and Massachusetts take up to three years to reach sexual maturity (Belding, 1930; Loosanoff, 1937), whereas in Georgia and Florida it takes as little as one year (Hesselman et al., 1988; Walker and Heffernan, 1995). 
The genus Mercenaria first appears in the fossil record during the Oligocene in deposits along the Gulf and Atlantic Coastal Plains of the United States (Stenzel, 1955; Harte, 2001). Today, two extant species of Mercenaria exist within the MACP and GCP: $M$. mercenaria (northern hard clam) and $M$. campechiensis (southern hard clam). Modern $M$. mercenaria ranges from Canada to central Florida, whereas $M$. campechiensis ranges from North Carolina to Florida and are more commonly found offshore in their northern limits (Dillon and Manzi, 1989; Carriker, 2001; Harte, 2001). While both species are abundant, fisheries primarily target $M$. mercenaria for human consumption because of their longer shelf life (MacKenzie et al., 2001; Arnold et al., 2009).

\section{Mercenaria species identification}

The two extant species of Mercenaria along the MACP and GCP, M. mercenaria and $M$. campechiensis, are traditionally identified by morphological and genetic analyses. The morphologic characteristics that distinguish the two species include interior shell color, shell thickness, shell shape, lunule shape, and concentric ridges on the outside of the shell (Dillon and Manzi, 1989; Harte, 2001). Mercenaria mercenaria are known to have purplish coloring along the posterior end of the shell that M. campechiensis lacks (Harte, 2001). Compared to M. mercenaria, M. campechiensis are thicker, shorter, rounder, larger, and have a shorter lunule length (Dillon and Manzi, 1989; Harte, 2001). Further, M. mercenaria have thin shell ridges that easily erode, whereas $M$. campechiensis have thicker shell ridges that generally do not entirely erode (Dillon and Manzi, 1989). In addition to the difference in morphology, isozyme frequencies differ significantly between the two species (Dillon and Manzi, 1989; Jones and Allmon, 1995). Given such isozyme differences, genetic analysis can identify the two species (e.g., Dillon and Manzi, 1989; Bert et al., 1993; Quitmyer et al., 1997; Arnold et al., 1998; Surge 
et al., 2008). Though past studies relied on morphological and genetic analyses to identify the two species (e.g., Dillon and Manzi, 1989; Bert et al., 1993; Quitmyer et al., 1997; Arnold et al., 1998; Surge et al., 2008), these analyses are not always diagnostic.

The general morphology of $M$. campechiensis closely resembles $M$. mercenaria and have been considered a conspecific with M. mercenaria in the past (Arnold et al., 1998; Harte, 2001). Juvenile $M$. campechiensis shells are known to resemble $M$. mercenaria more than adult $M$. campechiensis, making identification of juvenile Mercenaria species complicated (Harte, 2001). Further, shell morphology alone is not an accurate delimiting characteristic of the two species given the dependence of shell morphology on environmental conditions such as nutrient availability, substrate, temperature, and salinity (Kondo, 1987; Stanley, 1988; Harte, 2001). Identifying these two species becomes more problematic due to their tendency to hybridize (Dillon Jr. and Manzi, 1992; Bert et al., 1993; Powell, 2000), which is common in regions where they co-occur. For example, in the Indian Lagoon River on the Atlantic coast of Florida. Dillion and Manzi (1989) report that approximately $87.5 \%$ of the individuals are hybrids. They also report individuals that morphologically identify as $M$. mercenaria contained alleles of $M$. campechiensis and vice versa. Given these challenges, distinguishing between $M$. mercenaria and $M$. campechiensis is not always straight forward, especially in the fossil record.

\section{Methods}

\subsection{North Carolina fossil Mercenaria identification}

Identification of modern Mercenaria is sometimes challenging and becomes more problematic in the fossil record. The necessary tissue for genetic analysis of $M$. mercenaria and M. campechiensis is not preserved in the fossil record, and therefore, genetic analysis is not possible with fossil specimens. Thus, species identification of fossil Mercenaria shells primarily 
relies on morphological characteristics (Jones and Allmon, 1995; Winkelstern et al., 2013).

Preservation can pose challenges when using morphological characters. For example, pigmentation and exterior shell ridges and lunule lengths, useful in distinguishing modern species, are not preserved or have been modified by transportation and deposition such that they are no longer useful.

To determine if species of Mercenaria have disparate life history traits and how uncertainty in identification of our fossil specimens might influence our results, we compared the life history of six identified fossil Mercenaria specimens, $M$. permagna (n=3), and $M$. campechiensis (n=3), to our Mercenaria spp. from the Duplin Formation. M. permagna and $M$. campechiensis samples were collected at the Duplin Formation locality used for this study and provided by the North Carolina Museum of Natural Sciences. We chose M. permagna for this comparison because their more elongated and less inflated shell is easy to distinguish from that of M. mercenaria and M. campechiensis. (Tuomey and Holmes, 1857; Bush et al., 1999; Dillon and Manzi, 1989; Harte, 2001) (Figure. 2). 

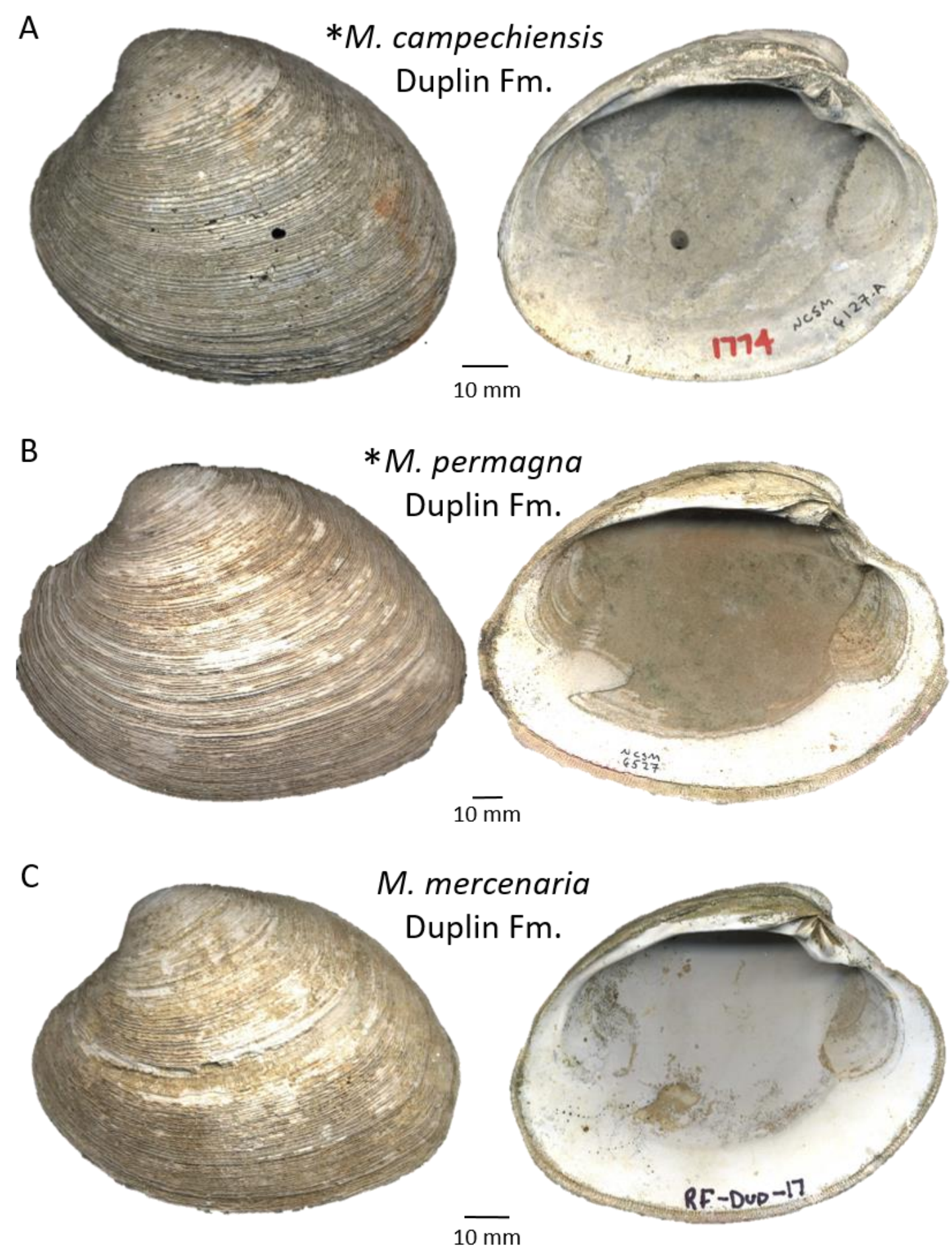

Figure. 2. Interior and exterior images of (A) M. campechiensis, (B) M. permagna, and (C) M. mercenaria from the Duplin Formation. *=Samples from the North Carolina Museum of Natural Sciences. 


\subsection{Sample selection and preparation}

We selected approximately 25 fossil and modern shells from each study site $(n=188)$ for life history analysis. When possible, we selected only the right valves for analysis to avoid potentially counting growth increments in the same individual more than once. Shells were selected based on preservation and taphonomic grade. Specimens with poor preservation in the hinge region, due to biological activities (i.e., boring), were discarded. Individuals were first labeled and scanned with an accompanying scale using an Epson GT-15000 Professional Scanner to preserve their two-dimensional measurements. Shell length (anterior to posterior) and maximum height (dorsal to ventral) were measured using digital calipers to the nearest $0.01 \mathrm{~mm}$ for each specimen. Previous work has shown Mercenaria species to form annual growth increments in the hinge region (e.g., Jones et al., 1989, 1990; Quitmyer et al., 1997; Ridgway et al., 2011b; Winkelstern et al., 2014), and we presume those here are annual as well (Figure. 3). To prevent loss of shell material when serially cutting specimens along the maximum axis of growth, we coated each shell with a layer of epoxy resin (Gorilla Glue Clear Epoxy) and allowed them to cure in a fume hood for at least 24 hours. Shells were cut using a Lortone Lapidary Trim Saw model FS6. Thick sections were made using a Buehler Isomet low-speed saw. Each thick section was polished using a Buehler MetaServ 2000 variable speed grinder/polisher with a 600 grit silicon carbide disc and finished with diamond suspension solutions of 1 and $6 \mu \mathrm{m}$. Polished cross-sections were imaged using an Olympus DP71 12.5-megapixel digital camera attached to an Olympus SZX7 stereomicroscope. Annual growth increments were counted and measured using Olympus Stream Essentials version 2.2 imaging software. 


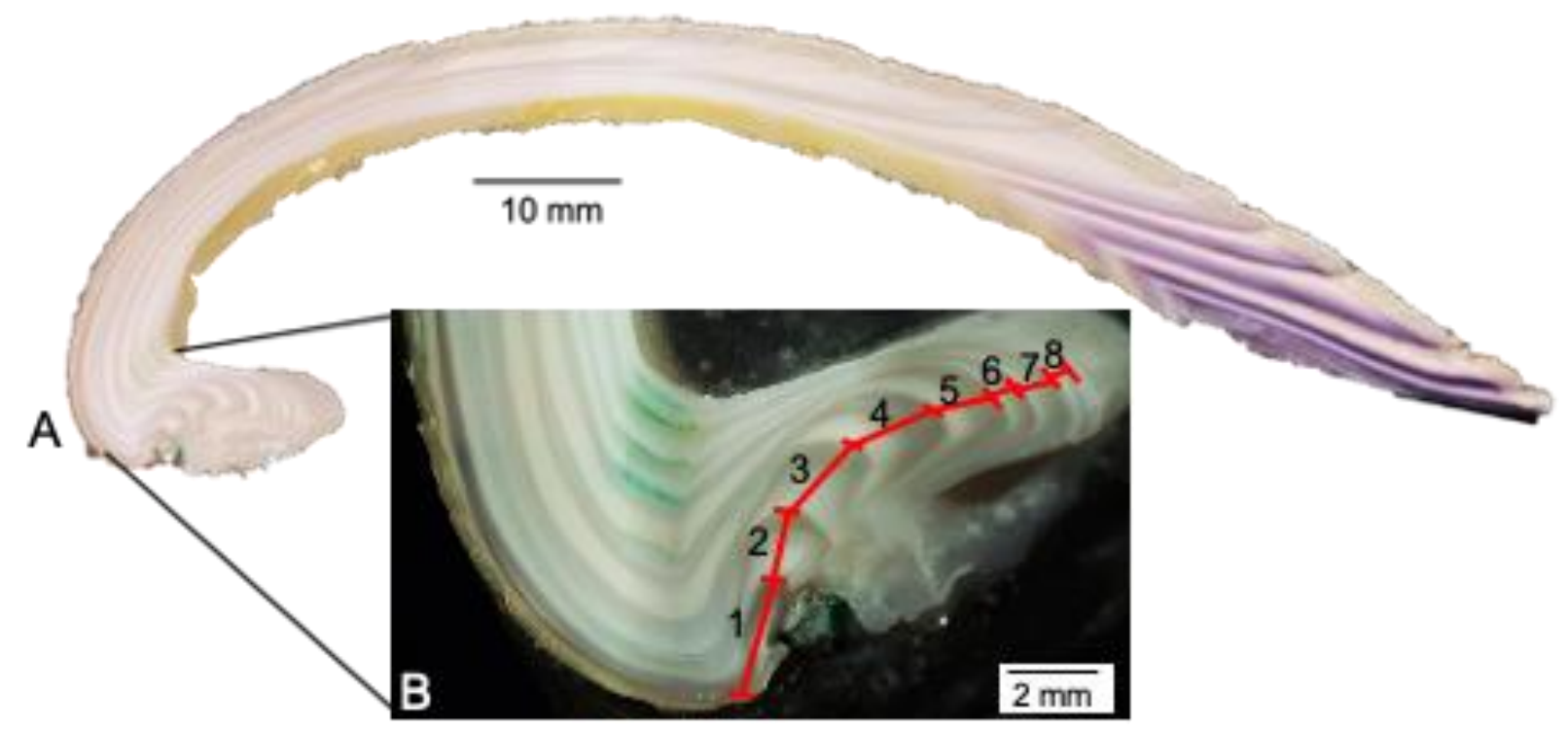

Figure. 3. A) Mercenaria spp. thick section from North Carolina cut along the along the axis of maximum growth. B) Couplets of light and dark increments in the hinge region under reflected light representing annual growth, and numbers represent ontogenetic growth years.

\subsection{Life history analysis}

To understand how life history parameters relate to climate state, we use the von Bertalanffy growth (VBG) equation (Bertalanffy, 1938):

$$
\mathrm{Lt}_{\mathrm{t}}=\mathrm{L}_{\infty}(1-\mathrm{e}(\mathrm{k}(\mathrm{t}-\mathrm{t} 0))
$$

where $\mathrm{Lt}_{t}$ is shell length at time $\mathrm{t}, \mathrm{L}_{\infty}$ is the asymptotic size, $\mathrm{k}$ is the rate at which $\mathrm{L}_{\infty}$ is approached, and to is the time at which Lt equals zero. We fit the VBG equation to the pooled size-at-age data using the non-linear least squares (nls) procedure in the open-source $\mathrm{R}$ language (cran.r.project.org). The parameter $\mathrm{k}$ acts as a proxy, though not a direct measure of growth rate. Individuals with higher $\mathrm{k}$ values typically approach $\mathrm{L}_{\infty}$ quicker than those with lower $\mathrm{k}$ values. In addition to using a population VBG equation, we also examine the lifespan for each individual 
specimen in the dataset. We use Tukey's Honestly Significant Difference to assess the variance in lifespan through space and time.

\section{Results}

\subsection{Life history of M. campechiensis and M. permagma}

By comparing the life history of fossil M. campechiensis and M. permagna to our samples from the Duplin Formation, we evaluated whether uncertainty in species identification would influence our results. The growth curves of $M$. campechiensis and M. permagna from museum collections fall within the range of our pooled population of Mercenaria spp. (Figure. 4). The lifespans of M. campechiensis (15-22 years) and M. permagna (10-26 years) also fall within the range of the lifespans of our Mercenaria spp. population (7-34 years). The same pattern is present in k values for $M$. campechiensis (0.13-0.46) and M. permagna (0.12-0.43) compared to our Mercenaria spp. population (0.14-0.46). The overlap in life history parameters gives us confidence that distinguishing between morphologically similar species in our fossil populations will not significantly influence our conclusions. 


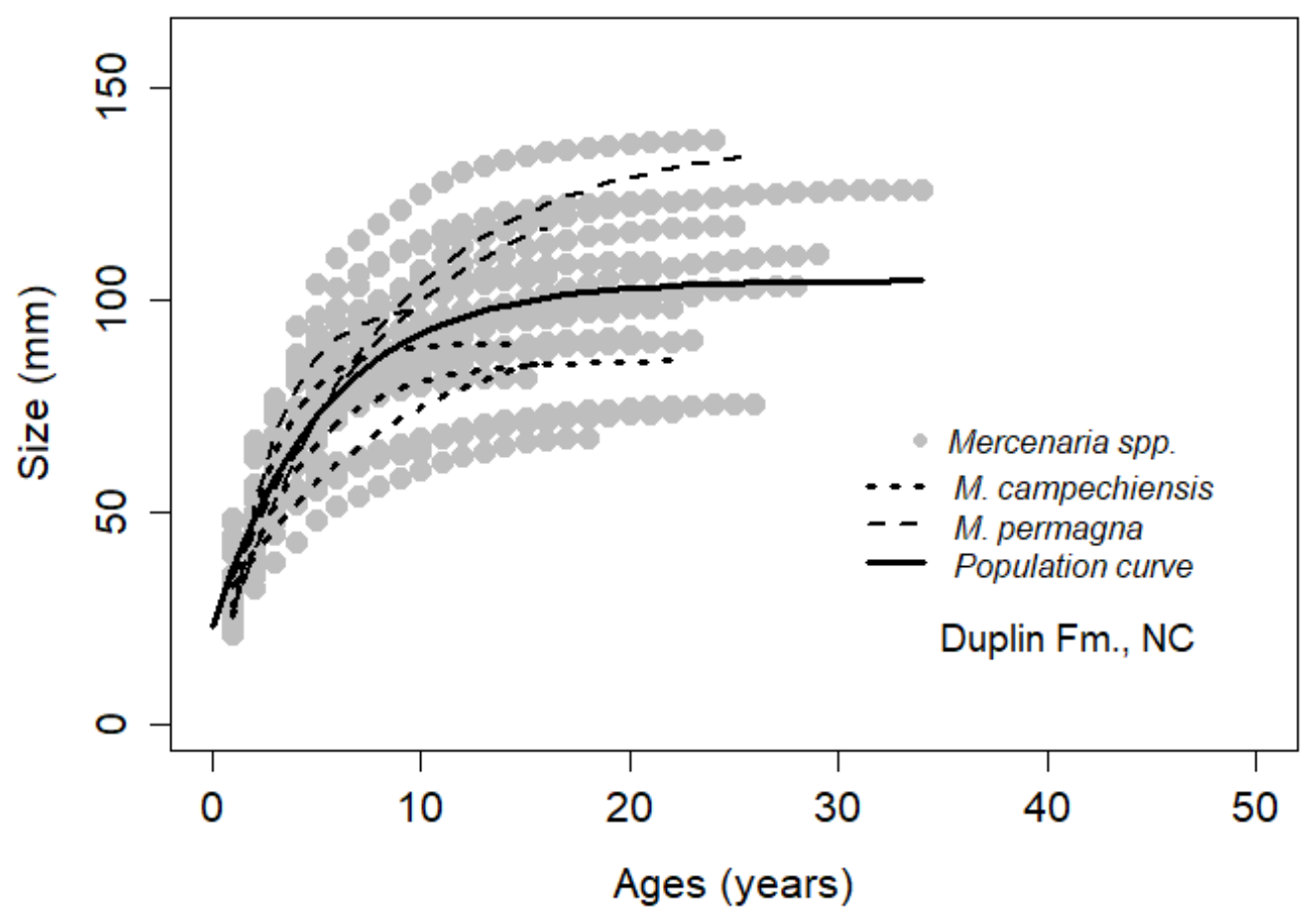

Figure. 4. Growth curves for identified specimens of M. campechiensis and M. permagna from collections at the North Carolina Museum of Natural history compared to our Mercenaria spp. from the same locality.

\subsection{Population-level lifespan and growth rate}

Well-preserved annual growth increments in Mercenaria spp. allow us to compare population life history parameters through space and time (Figure. 5; Table 1). Best fit VBG curves for fossil populations show differences in von Bertalanffy k. During the MPWP, $\mathrm{k}$ is higher in the Pinecrest Beds (0.27) from Florida than in the Duplin Formation (0.18) from North Carolina. A similar pattern is present in the early Pleistocene where the southernmost $\mathrm{k}$ value from the Caloosahatchee Formation (0.28) is higher than the northernmost $\mathrm{k}$ value from the Lower Waccamaw Formation (0.09). Our modern populations do not follow this trend. The $\mathrm{k}$ value of modern shells from Florida (0.18) is lower than shells from North Carolina (0.31). MLSP are similar in each population from the Pliocene (Pinecrest Beds=34 years; Duplin=34 
years) and Pleistocene (Caloosahatchee $=48$ years; Lower Waccamaw $=47$ years) but different in the modern Florida (35 years) and North Carolina (23 years) populations. It is important to note that modern shells were collected alive, so we assume they could have lived longer; thus, their lifespans and perhaps von Bertalanffy k values might be different than that from a natural death assemblage.

To further understand the influence temperature has on life history, we compared patterns in $\mathrm{k}$ and MLSP through time at similar latitudes during the MPWP and early Pleistocene. In the Florida populations, the k values of the MPWP Pinecrest Beds (0.27) and early Pleistocene Caloosahatchee Formation (0.28) are similar but they are higher than the modern population (0.18). For North Carolina, the k value of the MPWP Duplin Formation (0.18) is higher than the early Pleistocene Lower Waccamaw Formation (0.09) but both values are lower than the modern population (0.31). While MLSP during a time interval does not show difference between the Florida and North Carolina localities, it does change from the Pliocene to the Pleistocene at similar latitudes. The Pinecrest Beds show shorter maximum lifespans (34 years) than the Caloosahatchee Formation (48 years) but are similar to the modern population (35 years) from Florida. The mid Pliocene Duplin Formation MLSP (34 years) is shorter than the Pleistocene Lower Waccamaw Formation (47 years), and both are longer than the modern population (23 years). 

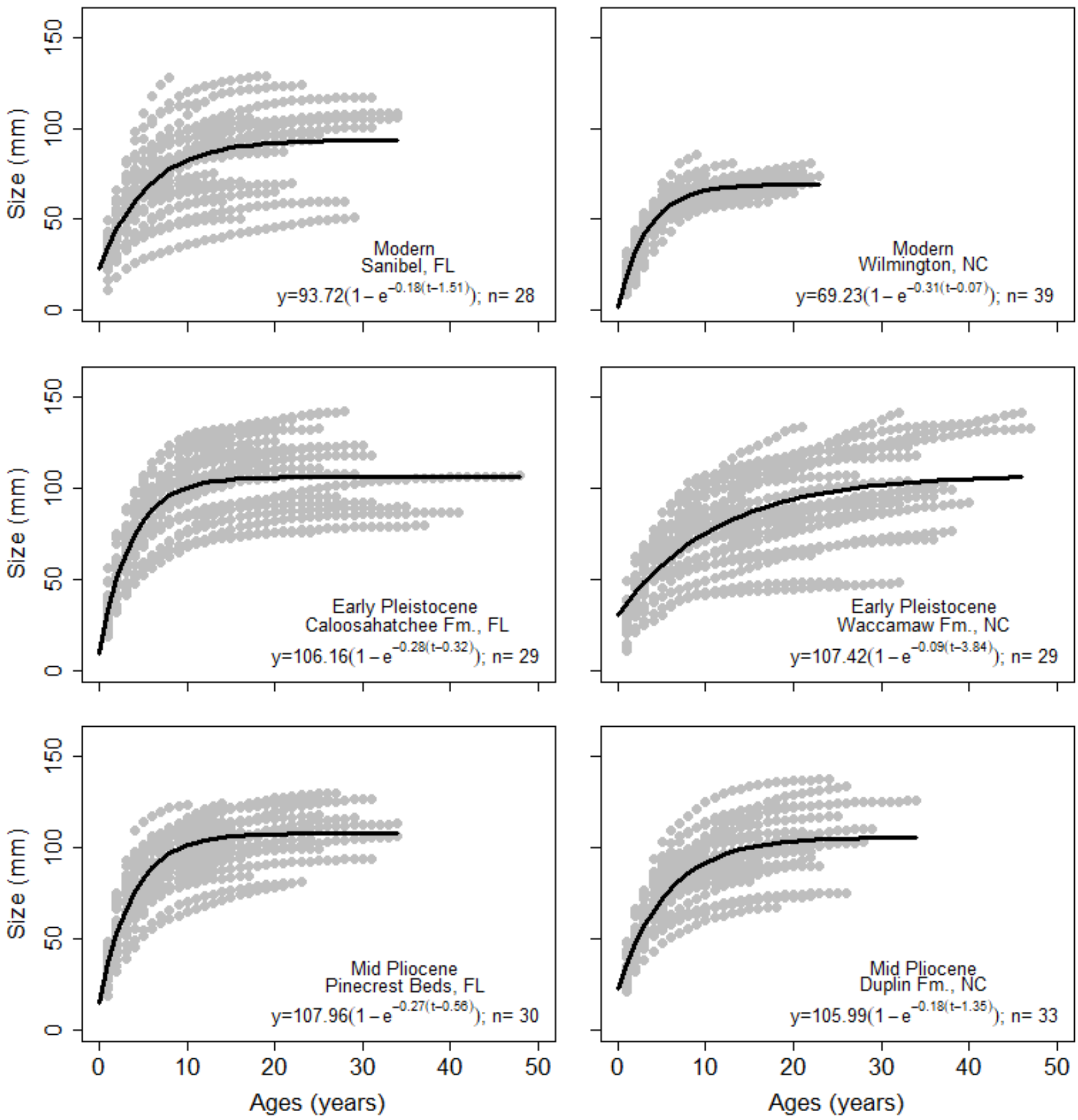

Figure. 5. von Bertalanffy growth curves fit to modern and fossil Mercenaria spp. size-at-age data. Gray circles=individual data points; solid black line=best fit population von Bertalanffy curve. 
Table 1. Calculated von Bertalanffy growth parameters for populations. DUP=Duplin Formation; WAC=Lower Waccamaw Formation; SANC=Modern North Carolina; PINE=Pinecrest Beds; CAL=Caloosahatchee formation; and SFL=Modern Florida.

\begin{tabular}{lccccc} 
Population & nshells & MLSP & $\mathrm{k}$ & $\mathrm{L}_{\infty}$ & $\mathrm{t} 0$ \\
\hline \hline Modern & & & & & \\
SANC, NC & 39 & 23 & 0.31 & 69.23 & -0.07 \\
SFL, FL & 28 & 35 & 0.18 & 93.72 & -1.51 \\
$\begin{array}{l}\text { Early Pleistocene } \\
\text { WAC, NC }\end{array}$ & 29 & 47 & 0.09 & 107.42 & -3.84 \\
CAL, FL & 29 & 48 & 0.28 & 106.16 & -0.32 \\
Mid Pliocene & & & & & \\
DUP, NC & 33 & 34 & 0.18 & 105.99 & -1.35 \\
PINE, FL & 30 & 34 & 0.27 & 107.96 & -0.56 \\
\hline
\end{tabular}

\subsection{Individual shell lifespan}

We analyzed variation in individual lifespans through space and time using Tukey's Honestly Significant Difference (Figure 6; Table 2 and Table 3). Spatially, during the MPWP, we found no significant difference $(\mathrm{p}>0.05)$ in mean lifespans, but during the early Pleistocene we did find a significant difference $(\mathrm{p}<0.05)$ as individuals from the Lower Waccamaw Formation $(24$ years; $\sigma=9.13$ ) are longer lived than those from the Caloosahatchee Formation (31 years; $\sigma=7.91$ ). We also found significant differences between our modern populations. The mean lifespan of the modern Florida shells (21 years; $\sigma=7.93$ ) is significantly higher than the modern North Carolina shells (16 years; $\sigma=4.59$ ). However, these differences could be due to sampling strategy which we discuss below. Temporally, we found no significant difference between individuals from Florida through time - mean lifespans do not change in our southern-most populations regardless of climate state. However, we did find a significant difference between our higher latitude populations from North Carolina through time. Mean lifespan of the Lower Waccamaw 
Formation (31 years; $\sigma=7.91$ ) is significantly higher than the Duplin Formation (20 years; $\sigma=6.10)$ and significantly lower than modern North Carolina specimens ( 16 year; $\sigma=4.59$ ).

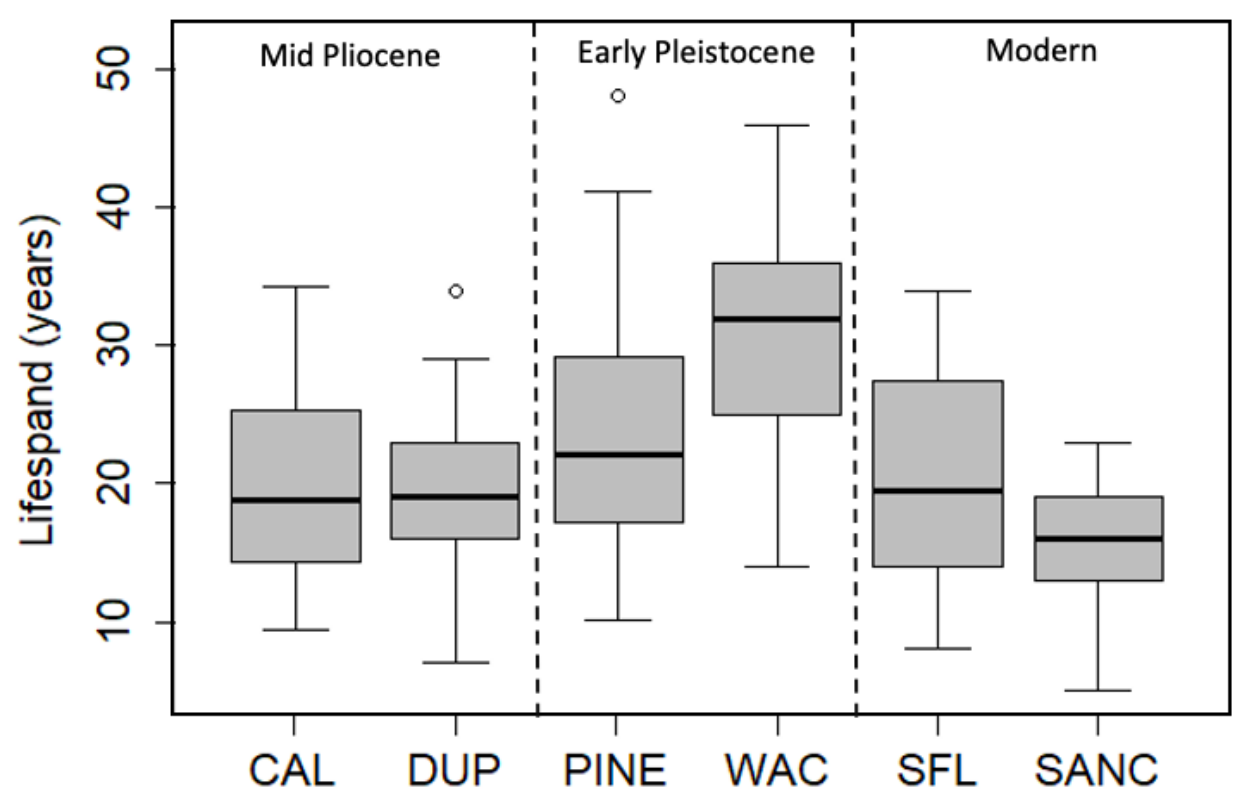

Figure. 6. Box plot of lifespans for each population. 
Table. 2. Summary of life history parameters for fossil and modern Mercenaria spp. populations with standard deviation $(\sigma)$, maximum (MAX), and minimum (MIN) values. LSP=mean lifespan. DUP=Duplin Formation; WAC=Lower Waccamaw Formation; SANC $=$ Modern North Carolina; $\mathrm{PINE}=$ Pinecrest Beds $; \mathrm{CAL}=$ Caloosahatchee Formation ; and SFL=Modern Florida.

\begin{tabular}{lccccc} 
Population & nshells & LSP & $\sigma$ & MIN & MAX \\
\hline \hline Modern & & & & & \\
SANC, NC & 39 & 15.56 & 4.59 & 5 & 23 \\
$\begin{array}{l}\text { SFL, FL } \\
\text { Early Pleistocene }\end{array}$ & 28 & 20.25 & 7.93 & 8 & 34 \\
WAC, NC & 29 & 30.21 & 7.91 & 14 & 46 \\
CAL, FL & 29 & 23.93 & 9.13 & 10 & 48 \\
Mid Pliocene & & & & & \\
DUP, NC & 33 & 19.33 & 6.10 & 7 & 34 \\
PINE, FL & 30 & 20.13 & 7.39 & 9 & 34 \\
& & & & & \\
\hline
\end{tabular}

Table 3. Tukey Honestly Significant Difference test results. PINE=Florida, Mid Pliocene Warm Period; $\mathrm{CAL}=$ Florida early Pleistocene; $\mathrm{SFL}=$ Florida, Modern; DUP=North Carolina, Mid Pliocene Warm Period; WAC=North Carolina, early Pleistocene; SANC=North Carolina, modern. $\mathrm{p}<0.05=$ significant difference in lifespan.

\begin{tabular}{cccccc} 
& PINE & CAL & SFL & DUP & WAC \\
\hline \hline & & & & & \\
CAL & 0.33 & & & & \\
SFL & 0.99 & 0.38 & & & \\
DUP & 0.99 & 0.12 & 0.99 & & \\
WAC & $<0.05$ & $<0.05$ & $<0.05$ & $<0.05$ & \\
SANC & 0.10 & $<0.05$ & 0.09 & 0.23 & $<0.05$ \\
& & & & & \\
\hline
\end{tabular}




\section{Discussion}

\subsection{Fossil Mercenaria life history: space and time}

To interpret changes of life history in our ancient populations spatially and temporally, it is important to understand what influences these parameters in modern settings. Previous work has established that both within specific groups, and across the Bivalvia as a whole, the pace of life is faster in the tropics than at the poles. Low-latitude bivalves typically grow faster and die younger than their high-latitude counterparts (Moss et al., 2016). Strong relationships with latitude suggest some sort of environmental control on life history. Longer lifespans seem to be promoted across a range of groups by lower metabolic rates (e.g., Van Voorhies, 2001). Metabolic rates are in part a function of body size and temperature (Gillooly et al., 2001); they are faster at higher temperatures and larger body sizes. In addition to temperature, metabolic rates are also regulated by food availability. In high-latitude settings, where food can be extremely seasonal because of polar light regimes, metabolic rates can be quite low for significant periods of time (Peck and Conway, 2000; Brockington and Clarke, 2001; Clarke et al., 2004; Norkko et al., 2005; Sato-Okoshi and Okoshi 2008). Thus, the modern pattern of increasing lifespan and decreasing growth rate towards the poles is likely driven by some combination of cool temperatures and low and seasonal food availability, though a recent analysis suggests that temperature might be more important (Saulsbury et al., 2019).

Our data from the MPWP and early Pleistocene lend support to the idea that temperature is an important control on life history. Best fit von Bertalanffy $\mathrm{k}$ values from Florida sites are higher than those from sites in North Carolina during both the MPWP and the early Pleistocene. When in a colder climate state, Florida k values show little change from the Pliocene to the 
Pleistocene (0.28 to 0.27 ), whereas k values from North Carolina populations show a much more dramatic change (0.18 to 0.09). Latitudinal climate gradients in the MACP and GCP were likely much steeper in the early Pleistocene than in the Pliocene (Cronin and Dowsett, 1990; Krantz, 1990; Cronin, 1991; Willard et al., 1993). Thus, the steepening of our von Bertalanffy k gradients in the early Pleistocene might be closely related to decreasing temperatures at midlatitudes, especially during the winter.

The relationship between lifespan though, is not as clear, at least spatially. During both the MPWP and early Pleistocene, not only are the maximum reported lifespans similar, but there is no difference in mean lifespans of each population between Florida and North Carolina. However, we do see a shift temporally in lifespans. From the MPWP to the cooler early Pleistocene, maximum reported lifespan increased by over 10 years ( 34 to 48 , respectively). Maxima of any trait are inherently tricky to estimate as increased sampling would likely result in an older individual. When we examine our populations in more detail and consider mean lifespans from the two intervals (Table 2), we see a statistically significant shift in North Carolina populations when temperatures decrease (Table 3). However, our populations show no significant change in lifespans regardless of climate state, even when comparing fossil and modern lifespans.

Cooler temperatures in the early Pleistocene, especially at our mid-latitude sites in North Carolina, seem to be promoting slow growth (lower k values) and longer lifespan. In contrast, life history traits of our low latitude sites seem to be less impacted by climate state than those at mid-latitudes. Even though the early Pleistocene was a cooler time globally, low latitude temperatures did not change significantly (Dowsett and Cronin, 1990; Cronin, 1991; Willard et al., 1993; Tao, 2012) and neither did life history parameters. This might have significant 
evolutionary implications. Today, metabolic rates of bivalves are faster at lower latitudes (Vladimirova et al., 2003), where von Bertalanffy k values are highest. During both the MPWP and the early Pleistocene, Mercenaria k values are higher in the tropics than they are at midlatitudes, which might suggest metabolic rates are higher too. Lower latitudes might thus facilitate higher metabolic rates and von Bertalanffy $\mathrm{k}$ values through time regardless of global climate state. If this hypothesis is correct, and growth is always faster in the tropics, this might not be unrelated to latitudinal diversity gradients through time (e.g., Mannion et al., 2014). It could also help provide a mechanism for the "out of the tropics" model of Jablonski and others (2006, 2013) as shorter lived, faster growing tropical species would reproduce earlier, and might be more likely to spin off new species more frequently than their slower growing, longer-lived, higher latitude counterparts.

\subsection{Life history of modern Mercenaria}

Our life history data for modern Mercenaria do not show the expected trend of increasing lifespan and decreasing growth rate with latitude. Individuals from our Florida population grow slower $(\mathrm{k}=0.18)$ and live longer $(\mathrm{MLSP}=35)$ than those from North Carolina $(\mathrm{k}=0.31$, MLSP=23). While this would seem to raise questions to the patterns we observe in the fossil record, a number of factors could be influencing our modern data set, which we discuss below.

Habitat-specific conditions such as depth, sediment type, and salinity influence the growth of Mercenaria. For example, salinities below 15 psu and above 32 psu can inhibit Mercenaria growth and long-term survival (Chanley, 1957; Castagna, 1973; Winkle et al., 1976). Studies have also shown variation in growth rates of Mercenaria in response to sediment types. For example, Mercenaria from substrates with higher sand continent tend to have faster growth rates compared to those from muddy bottoms (Grizzle and Morin, 1989). Similarly, 
Mercenaria tend to have faster growth rates on vegetated compared to unvegetated seafloors (Arnold et al., 1991; Slattery et al., 1993). Finally, Mercenaria living at deeper depths tend to grow slower than those at shallower depths because of a decrease in seasonal food availability and interference in filtering by resuspended bottom sediments (Arnold et al., 1991). Habitat specific differences in environmental conditions are not likely influencing our modern samples. Shells were collected from the bay sides of Sanibel and Masonboro Islands in Florida and North Carolina, respectively. These localities all have sandy to muddy bottoms absent of high vegetation, and shells were collected at depths of approximately $1 \mathrm{~m}$. However, the most significant difference in environmental conditions is in the fresh and open ocean water influences at each site. Our North Carolina locality has restricted access to the open ocean through the Masonboro inlet and limited freshwater inflow occurs primarily through the Hewletts and Whisky Creeks. The salinity of this locality ranges from 11.8-37.1 psu (https://cdmo.baruch.sc.edu/dges/). In comparison, Florida localities receive significant freshwater inflow from the Caloosahatchee River. However, these localities are also exposed to the open ocean through the opening between Sanibel Island and Punta Rassa and multiple inlets along Sanibel Island. Salinity within this region range 22.6-34.7 psu (https://my.sfwmd.gov/dbhydroplsql/show_dbkey_info.main_menu). Both sites then, typically fall within the normal range of salinity for Mercenaria and we do no suspect these differences are influencing life history significantly.

Sampling procedures likely played a role in the life history patterns we see in modern North Carolina Mercenaria. Our samples were all collected alive from the same small area within UNCW's marine sanctuary, which is a protected marine habitat. When we examine their age distribution, we found that they have not only the shortest reported maximum lifespan, but 
also smallest mean lifespan (16 years, $\sigma=4.59$ ) of any of our populations sampled, modern or fossil. This finding likely means that we have sampled what might be a few cohorts or groups of individuals that represent only a few spat falls. It is possible that this population was collected too early, and undoubtedly had we left them alone, they would have lived longer. It is difficult to compare the life history of our modern North Carolina shells since they are probably not a true representation of modern populations. Our Florida samples on the other hand were obtained from museums which were collected from various localities over a span of approximately 25 years, and they might be more representative of a modern population, and perhaps more comparable to a fossil population given an artificially introduced degree of time mixing

Finally, our inability to recapture a modern latitudinal life history trend in Mercenaria might be due to the noisy nature of life history data themselves. The modern latitudinal life history gradient not only shows inverse trends in lifespan and von Bertalanffy k, but also demonstrates that variance in these traits is not equal across latitude. In fact, with von Bertalanffy k, variance decreases with increasing latitude, whereas with lifespan, variance increases with increasing latitude. Thus, at any given latitude, we should expect to see some range in life history parameters. Growth rates and lifespans of modern Mercenaria populations are well studied throughout their biogeographic range (Hopkins, 1930; Saloman and Taylor, 1969; Peterson et al., 1983; Walker and Tenore, 1984; Peterson, 1986; Jones et al., 1990; Arnold et al., 1991; Slattery et al., 1993; Eversole et al., 2000; Surge and Walker, 2006), and when we incorporate data from other studies (Figure. 7), latitudinal trends in life history of modern Mercenaria from Florida to North Carolina become more apparent. Our von Bertalanffy k value for Florida falls towards the lower range of what was expected, and our maximum lifespan appears to be a record for that latitude. Published data from North Carolina are more spares, but 
our von Bertalanffy k value does not fall too far outside the reported range. In addition, data from other researchers suggest that at that latitude, we would likely find much older individuals with more, and perhaps better, targeted sampling.

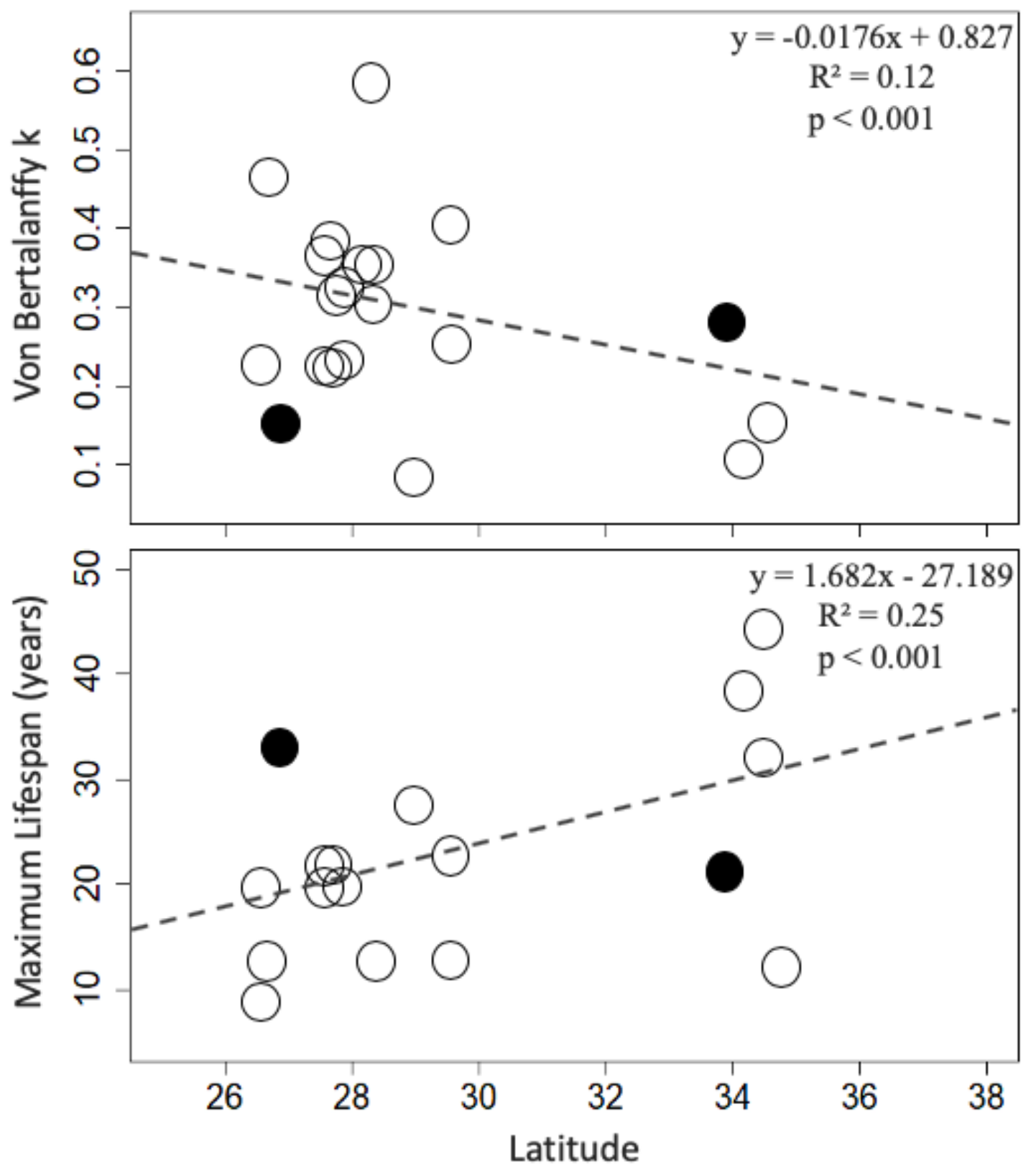

Figure. 7. Top: Relationship between latitude and k value of modern Mercenaria spp. Bottom: Relationship between latitude and lifespan of modern Mercenaria spp. Solid circles=our study. Empty circles=k and lifespan values from the following publications: Hopkins (1930), Saloman 
and Taylor (1959), Peterson et al. (1983), Walker and Tenore (1984), Peterson (1986), Jones et al. (1990), Arnold et al. (1991), Slattery et al. (1991), Eversole et al. (2000), and Surge and Walker (2006).

\subsection{Implications for Conservation Paleobiology}

Bivalve shellfishing contributes over $\$ 800,000,000$ annually to the US marine fisheries industry (https://www.fisheries.noaa.gov/national/sustainable-fisheries/commercial-fisheries-landings), yet the impact of climate and environmental change on shellfisheries are only now starting to be understood. Recent studies on growth of the long-lived Arctica islandica, a primary source in the U.S. of clam chowder, have found significant impacts of rising global temperatures over the past century and a half. Off the coast of the eastern U.S., living A. islandica now reach $80 \mathrm{~mm}$, the size at which they are selected by commercial dredges, in approximately 30 years, compared to about 60 years in the early 1800s (Pace et al., 2018). In the Atlantic Surfclam, Spisula solidissima, populations have been pushed further offshore and into deeper water off Long Island. This shift has caused increased starvation mortality as decreased food availability at deeper depths is not sufficient to maintain respiration rates in older, larger individuals (Narváez et al., 2015, Munroe et al., 2016). Both of these changes in life history strategy took place over an approximately $1^{\circ} \mathrm{C}$ increase in seawater temperature.

How will life histories of modern marine bivalves change if the highest estimates of the IPCC $\left(4.8^{\circ} \mathrm{C}\right)$ are reached? Much like in modern bivalves, our fossil data show a strong relationship between temperature and growth rate: as temperature increases growth rates increase at our mid-latitude site. In the cooler Pleistocene, Mercenaria spp. from North Carolina took approximately 20 years to reach $100 \mathrm{~mm}$, whereas in the Pliocene, this size was attained in only 10 years. However, growth and lifespan does not change significantly at the lower latitude sites, 
perhaps because temperatures in tropical regions are more stable even when going from greenhouse to icehouse climate states. These observations suggest that in response to increasing seawater temperatures, life history patterns in low-latitude Mercenaria may not change appreciably, but those from mid-latitudes may shift to faster growth rates. Thus, mid-latitude populations may reach a harvestable size and sexual maturity quicker. Faster growth would be predicted to come with shorter lifespans as the two are inversely related. What either might mean for the future of Mercenaria harvestability at mid-latitudes remains somewhat unclear as the relationship between lifespan and fecundity has not been seriously addressed. Either way, it could have serious impacts on population management and accounting for such responses will be critical when constructing management plans, harvesting seasonings, and even catch allowances. Given the reliance of shellfisheries on this species, it is important to understand these potential responses to properly prepare for what future shellfisheries might face with projected environmental change.

\section{Conclusion}

The potential response of marine organisms to rising seawater temperatures remains uncertain. This uncertainty is in large part due to the time scale over which these processes happen. Fortunately, the fossil record provides us an opportunity to explore how species have responded to environmental change in the past. Here, we turn to the fossil record to give us insight on how the economically and ecologically important bivalve genus, Mercenaria, might respond to projected increases in seawater temperature. We accomplished this by analyzing life history parameters of fossil Mercenaria spp. from climate intervals warmer than or comparable to today. Further, we examined how temperature influences these life history parameters by comparing growth rates and lifespans in fossil populations from the warm MPWP and subsequent cooling of 
the early Pleistocene. We found that growth rates vary with temperature. In general, specimens from warmer climates have faster growth rates compared to those from cooler climates.

However, the relationship between lifespan and climate state is not as clear. Further, we observe that individuals form low latitudes seem to be less impacted by climate state than those at mid latitudes. Given these findings, we suggest mid-high latitude individuals might experience shifts in growth rates, whereas low-latitude individuals might not experience such impacts. These findings provide useful data for conservation biology and restoration ecology that can be used to set policy or develop management plans in the face of projected future warming. 


\section{APPENDIX: LOCALITIES}

Appendix Table 1: Modern and fossil collection locality details. ND= no data.

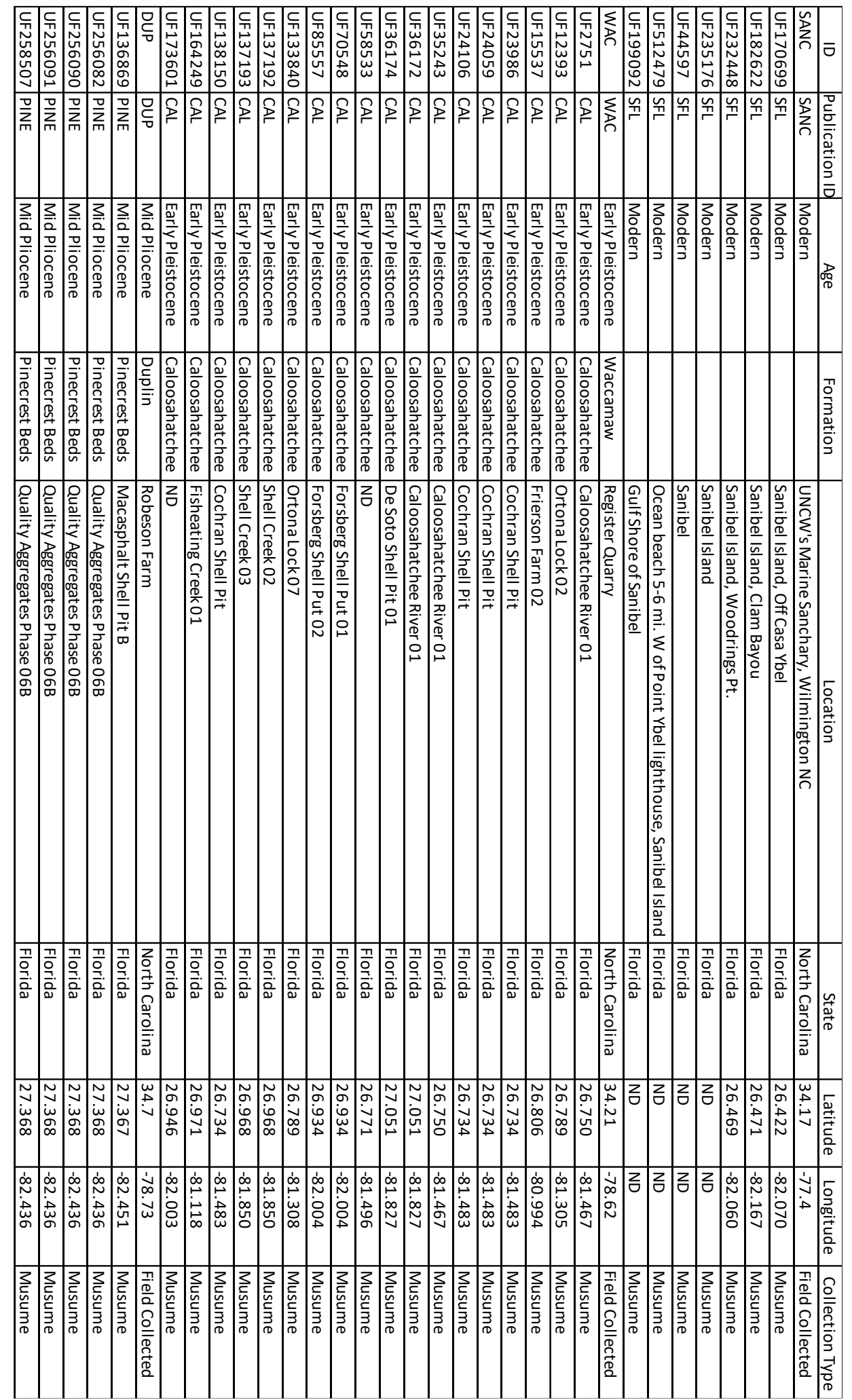




\section{APPENDIX: VON BERTALANFFY R CODE DOCUMENTATION}

\section{Setting starting parameters}

$R$ Code:

$\mathrm{K}=0.20$

Linf $=70$

$\mathrm{t} 0=1$

Documentation:

K Starting parameters for von Bertalanffy k

Linf Starting parameters for von Bertalanffy $L_{\infty}$

t0 Starting parameter for von Bertalanffy to

\section{Fitting von Bertalanffy growth equation to size at age data}

$R$ code:

$\mathrm{VB}=\mathrm{nls}\left(\operatorname{size} \sim \operatorname{Linf} *\left(1-\exp \left(-\left(\mathrm{K}^{*}(\right.\right.\right.\right.$ ages-t0) $\left.\left.)\right)\right)$,

$$
\text { start }=\operatorname{list}(\mathrm{K}=\mathrm{K}, \operatorname{Linf}=\operatorname{Linf}, \mathrm{t} 0=\mathrm{t} 0) \text {, }
$$$$
\text { control }=\operatorname{list}(\operatorname{maxiter}=1000,
$$$$
\text { warnOnly=TRUE)) }
$$

\section{Documentation:}

nls Nonlinear Least Squares

(https://www.rdocumentation.org/packages/stats/versions/3.6.2/topics/nls)

size size at age data

Linf Starting parameters for von Bertalanffy $\mathrm{L}_{\infty}$

K Starting parameters for von Bertalanffy k

ages size at age data

t0 Starting parameter for von Bertalanffy to

start a named list or named numeric vector of starting estimates. When start is

missing (and formula is not a self-starting model, see selfStart), a very cheap guess for start is tried (if algorithm != "plinear").

control an optional list of control settings. See nls.control for the names of the settable control values and their effect. 


\section{Getting population von Bertalanffy parameters}

$R$ Code:

$\mathrm{v}=\operatorname{coef}(\mathrm{VB})$

$\mathrm{y}=\mathrm{v}[2] *(1-\exp (-(\mathrm{v}[1] *(0: \#-\mathrm{v}[3]))))$

$\operatorname{plot}($ ages, size)

lines(0:\#, y,col="black", lwd=3)

Documentation:

coef(VB) extracting the fitted coefficients for the nonlinear Least Squares

plot plotting all size at age data

ages age at size data

size size data

lines adding calculated von Bertalanffy growth curve to population size at age data

\# $\quad$ MLSP for (different for each data set) 


\section{REFERENCES}

Abarca-del- Río, R., Crétaux, J-F., Berge-Nguyen, M., \& Maisongrande, P. (2012). Does the Titicaca Lake still control the Poopo lake water levels? An investigation using satellite altimetry, and MODIS data (2000-2009). Remote Sens. Lett., 3(8), 707-714. https://doi.org/10.1080/01431161.2012.667884

Allmon, W.D., (1993). Age, environment and mode of deposition of the densely fossiliferous Pinecrest Sand (Pliocene of Florida): Implications for the role of biological productivity in shell bed formation. Palaios, 8, 183-201. https://doi.org/10.2307/3515171

Ansell, A.D., (1968). The rate of growth of the hard clam Mercenaria mercenaria (L) throughout the geographical range. ICES J. Mar. Sci., 31, 364-409. https://doi.org/10.1093/icesjms/31.3.364

Ansell, A.D., (1962). Observations on burrowing in the Veneridae (Eulamellibranchia). Biol. Bull., 123, 521-530. https://doi.org/10.2307/1539573

Arnold, W.S., Bert, T.M., Quitmyer, I.R., Jones, D.S., (1998). Contemporaneous deposition of annual growth bands in Mercenaria mercenaria (Linnaeus), Mercenaria campechiensis (Gmelin), and their natural hybrid forms. J. Exp. Mar. Bio., Ecol. 223, 93-109. https://doi.org/10.1016/S0022-0981(97)00152-4

Arnold, W.S., Geiger, S.P., Stephenson, S.P., (2009). Mercenaria mercenaria introductions into Florida, USA, waters: Duration, not size of introduction, influences genetic outcomes. Aquat. Biol., 5, 49-62. https://doi.org/10.3354/ab00137

Arnold, W.S., Marelli, D.C., Bert, T.M., Jones, D.S., Quitmyer, I.R., (1991). Habitat-specific growth of hard clams Mercenaria mercenaria (L.) from the Indian River, Florida. J. Exp. Mar. Bio. Ecol., 147, 245-265. https://doi.org/10.1016/0022-0981(91)90185-Y

Belding, D.L., (1930). The quahog fishery of Massachusetts. Commonw. Mass. Dep. Conserv., Div. Fish. Game, Mar. Ser., 2, 41 pp.

Bender, M.L., (1973). Helium-uranium dating of corals. Geochim. Cosmochim. Acta, 37, 12291247. https://doi.org/10.1016/0016-7037(73)90058-6 
Bert, T.M., Hesselman, D.M., Arnold, W.S., Moore, W.S., Cruz-Lopez, H., Marelli, D.C., (1993). High frequency of gonadal neoplasia in a hard clam (Mercenaria spp.) hybrid zone. Mar. Biol., 117, 97-104. https://doi.org/10.1007/BF00346430

Bertalanffy, L. Von, (1938). A quantitative theory of organic growth (inquiries on growth laws. II). Hum. Biol., 10, 181-213. https://doi.org/10.1080/15505340.201

Blackwelder, B.W., (1981). Late Cenozoic stages and molluscan zones of the U.S. middle Atlan tic Coastal Plain. J. Paleontol., 55, 1-34. https://doi.org/10.1017/s0022336000061862

Brierley, C.M., Fedorov, A. V., Liu, Z., Herbert, T.D., Lawrence, K.T., LaRiviere, J.P., (2009). Greatly expanded tropical warm pool and weakened hadley circulation in the early Pliocene. Science, 323, 1714-1718. https://doi.org/10.1126/science.1167625

Briggs, J.C., (1995). Global biogeography. Developments in Palaeontology and Stratigraphy. Elsevier science, Amsterdam.

Briggs, J.C., Bowen, B.W., (2012). A realignment of marine biogeographic provinces with particular reference to fish distributions. J. Biogeogr., 39, 12-30. https://doi.org/10.1111/j.1365-2699.2011.02613.x

Brittl, R., Campbell, L., Campbell, M., Carter, J., (1992). Tarheel, Bladen County, North Caro lina. Guideb. F. Trips.

Brockington, S., \& Clarke, A., (2001). The relative influence of temperature and food on the me tabolism of a marine invertebrate. J. Exp. Mar. Biol. Ecol., 258, 87-99. https://doi.org/10.1016/S0022-0981(00)00347-6

Buddemeier, R.W., Maragos, J.E., Knutson, D.W., (1974). Radiographic studies of reef coral exoskeletons: Rates and patterns of coral growth. J. Exp. Mar. Bio. Ecol., 14, 179-199. https://doi.org/10.1016/0022-0981(74)90024-0

Bush, A.M., Bambach, R.K., Scheckler, S.E., (1999). Time-Averaging and Morphology : variability in modern populations and fossil assemblages of Mercenaria (Bivalvia). Unpublished masters dissertation. Virginia Polytechnic Institute and State University, $155 \mathrm{pp}$. 
Butler, P.G., Wanamaker, A.D., Scourse, J.D., Richardson, C.A., Reynolds, D.J., (2013).

Variability of marine climate on the North Icelandic Shelf in a 1357-year proxy archive based on growth increments in the bivalve Arctica islandica. Palaeogeogr.

Palaeoclimatol. Palaeoecol. 373, 141-151. https://doi.org/10.1016/j.palaeo.2012.01.016

Carriker, M.R., (2001). Embryogenesis and organogenesis of veligers and early juveniles. Dev. Aquac. Fish. Sci., 31, 77-115. https://doi.org/10.1016/S0167-9309(01)80031-4

Chanley, P.E., (1957). Survival of some juvenile bivalves in water of low salinity. Proc. Natl. Shellfish. Assoc., 48, 52-65.

Clarke, A., Prothero-Thomas, E., Beaumont, J.C., Chapman, A.L., Brey, T., (2004). Growth in the limpet Nacella concinna from contrasting sites in Antarctica. Polar Biol. 28, 62-71. https://doi.org/10.1007/s00300-004-0647-8

Collins, M., Knutti, R., Arblaster, J., Dufresne, J.-L., Fichefet, T., Friedlingstein, P., Gao, X., Gutowski, W.J., Johns, T., Krinner, G., Shongwe, M., Tebaldi, C., Weaver, A.J., Wehner, M.F., Allen, M.R., Andrews, T., Beyerle, U., Bitz, C.M., Bony, S., Booth, B.B.B., (2013). Long-term climate change: Projections, commitments and irreversibility., In: Climate change 2013 - The physical science basis: Working Group I contribution to the Fifth Assessment Report of the Intergovernmental Panel on Climate Change. Cambridge University Press, Cambridge, UK, pp. 1029-1136. https://doi.org/10.1017/CBO9781107415324.024

Cronin, T.M., (1991). Pliocene shallow water paleoceanography of the North Atlantic ocean based on marine ostracodes. Quat. Sci. Rev., 10, 175-188. https://doi.org/10.1016/02773791(91)90017-O

Cronin, T.M., (1988). Evolution of marine climates of the U.S. Atlantic coast during the past four million years. Philos. Trans. R. Soc. London. B, Biol. Sci., 318, 661-678. https://doi.org/10.1098/rstb.1988.0029

Cronin, T.M., Dowsett, H.J., (1990). A quantitative micropaleontologic method for shallow ma rine peleoclimatology: Application to Pliocene deposits of the western North Atlantic Ocean. Mar. Micropaleontol. 16, 117-147. https://doi.org/10.1016/0377-8398(90)90032H 
Cronin, T.M., Dowsett, H.J., 1996. xxxxIn: Evolution and Environment in Tropical America. pp. 76-104.

Dietl, G.P., Flessa, K.W., (2011). Conservation paleobiology: Putting the dead to work. Trends Ecol. Evol., 26, 30-37. https://doi.org/10.1016/j.tree.2010.09.010

Dietl, G.P., Kidwell, S.M., Brenner, M., Burney, D.A., Flessa, K.W., Jackson, S.T., Koch, P.L., (2015). Conservation paleobiology: Leveraging knowledge of the past to inform conservation and restoration. Annu. Rev. Earth Planet. Sci., 43, 79-103. https://doi.org/10.1146/annurev-earth-040610-133349

Dillon Jr., R.T., Manzi, J.J., (1992). Population genetics of the hard clam, Mercenaria merce naria, at the northern limit of its range. Can. J. Fish. Aquat. Sci., 49, 2574-2578. https://doi.org/10.1139/f92-284

Dillon, R.T., Manzi, J.J., (1989). Genetics and shell morphology in a hybrid zone between the hard clams Mercenaria mercenaria and M. campechiensis. Mar. Biol. 100, 217-222. https://doi.org/10.1007/BF00391961

Dowsett, H.J., (2007). The PRISM palaeoclimate reconstruction and Pliocene sea-surface temperature. Geol. Soc. Spec. Publ., pp. 459-480. https://doi.org/10.1144/tms002.21

Dowsett, H.J., Cronin, T.M., (1990). High eustatic sea level during the middle Pliocene: Evi dence from the southeastern U.S. Atlantic Coastal Plain. Geology, 18, 435-438. https://doi.org/10.1130/0091-7613(1990)018<0435:HESLDT>2.3.CO;2

Dowsett, H.J., Robinson, M.M., (2009). Mid-Pliocene equatorial Pacific sea surface temperature reconstruction: A multi-proxy perspective. Philos. Trans. R. Soc. A Math. Phys. Eng. Sci., 367, 109-125. https://doi.org/10.1098/rsta.2008.0206

Dowsett, H.J., Robinson, M.M., Foley, K.M., (2009). Pliocene three-dimensional global ocean temperature reconstruction. Clim. Past, 5, 769-783. https://doi.org/10.5194/cp-5-7692009

Eversole, A.G., (2001). Reproduction in Mercenaria mercenaria. In: Kraeuter, J., Castagna, N. (Eds.), Biology of the Hard Clam. Elsevier, pp. 221- 260. 
Eversole, A.G., Devillers, N., Anderson, W.D., (2000). Age and size of Mercenaria mercenaria in Two Sisters Creek, South Carolina. J. Shellfish Res., 19, 51-56.

Gardner, J.A., (1943). Mollusca from the Miocene and lower Pliocene of Virginia and North Carolina; Part I, Pelecypoda; with a summary of the stratigraphy by W. C. Mansfield. United States Geol. Surv. Prof. Pap., 199, pp. 1-178.

Gibson, T.G., (1987). Miocene and Pliocene Pectinidae (Bivalvia) from the Lee Creek mine and adjacent areas. In: Ray, C. (Ed.), Geology and Paleontology of the Lee Creek Mine, North Carolina, II. Smithsonian Contributions to Paleobiology, pp. 31-112.

Gibson, T.G., (1983). Key foraminifera from upper Oligocene to lower Pleistocene strata of the central Atlantic Coastal Plain. In: Ray, C. (Ed.), Geology and Paleontology of the Lee Creek Mine, North Carolina, I. Smithsonian Contributions to Paleobiology, pp. 355-453.

Gillooly, J.F., Brown, J.H., West, G.B., Savage, V.M., Charnov, E.L., (2001). Effects of size and temperature on metabolic rate. Science, 293, 2248-2251.

https://doi.org/10.1126/science.1061967

Grizzle, R.E, Bricelj, M., Shumway, S., (2001). Physiological ecology of Mercenaria merce naria. Dev. Aquac. Fish. Sci., 31, 305-382. https://doi.org/10.1016/S01679309(01)80036-3

Grizzle, R.E., Morin, P.J., (1989). Effect of tidal currents, seston, and bottom sediments on growth of Mercenaria mercenaria: results of a field experiment. Mar. Biol., 102, 85-93. https://doi.org/10.1007/BF00391326

Harte, M.E., (2001). Chapter 1 Systematics and taxonomy. Dev. Aquac. Fish. Sci., 31, 3-51. https://doi.org/10.1016/S0167-9309(01)80029-6

Hazel, J.E., (1977). Distribution of some biostratigraphically diagbostic ostracodes in the Plio cene and lower Pleistocene of Virginia and North Carolina. J. Reseach U.S Geol. Surv., 5, 373-388.

Hesselman, D.M., Blake, N.J., Peters, E.C., (1988). Gonadal neoplasms in hard shell clams Mercenaria spp., from the Indian River, Florida: Occurrence, prevalence, and histopathology. J. Invertebr. Pathol., 52, 436-446. https://doi.org/10.1016/0022$2011(88) 90056-0$ 
Hopkins, H.S., (1930). Age differences and the respiration in muscle tissues of mollusks. J. Exp. Zool., 56, 209-239. https://doi.org/10.1002/jez.1400560206

Jablonski, D., Belanger, C. L., Berke, S. K., Huang, S., Krug, A. Z., Roy, K., Tomasovych, A., \& Valentine, J. W., (2013). Out of the tropics, but how? Fossils, bridge species, and thermal ranges in the dynamics of the marine latitudinal diversity gradient. Proceedings of the National Academy of Sciences of the United States of America, 110, 10487-10494. https://doi.org/10.1073/pnas.1308997110

Jablonski, D., Roy, K., and Valentine, J.W., (2006). Out of the tropics: evolutionary dynamics of the latitudinal diversity gradient. Science, 314, 102-106.

Johnson, A.L.A., Valentine, A., Leng, M.J., Sloane, H.J., Schöne, B.R., Balson, P.S., (2017). Isotopic temperatures from the early and mid-pliocene of the US middle Atlantic Coastal plain, and their implications for the cause of regional marine climate change. Palaios, 32, 250-269. https://doi.org/10.2110/palo.2016.080

Jones, D., Allmon, W., (1995). Records of upwelling, seasonality and growth in stable-isotope profiles of Pliocene mollusk shells from Florida. Lethaia, 28, 61-74. https://doi.org/10.1111/j.1502-3931.1995.tb01593.x

Jones, D., Quitmyer, I., Arnold, W., Marelli, C., (1990). Annual shell banding, age, and growth rate of hard clams (Mercenaria spp.) from Florida. J. Shellfish Res., 9, 215-225.

Jones, D.S., (1988). Sclerochronology and the size versus age problem. In: McKinney, M.L. (Eds.) Heterochrony in Evolution. Topics in Geobiology, vol. 7,. Springer, Boston, MA, pp. 93-108. https://doi.org/10.1007/978-1-4899-0795-0_6

Jones, D.S., Macfadden, B.J., Webb, S.D., Mueller, P.A., Hodell, D.A., Cronin, T.M., (1991). Integrated geochronology of a classic Pliocene fossil site in Florida: linking marine and terrestrial biochronologies. J. Geol., 99, 637-648. https://doi.org/10.1086/629529

Jorgensen, C.B., (1975). Comparative physiology of suspension feeding. Annu. Rev. Physiol., 37, 57-79. https://doi.org/10.1146/annurev.ph.37.030175.000421

Keigwin, L.D., (1982). Stable isotope stratigraphy and paleoceanography of DSDP Sites 502 and 503. Geology, 445-453. https://doi.org/10.2973/dsdp. proc.68.119.1982 
Keigwin, L.D., (1978). Pliocene closing of the Isthmus of Panama, based on biostratigraphic evidence from nearby Pacific Ocean and Caribbean Sea cores. Geology, 6, 630-634. https://doi.org/10.1130/0091-7613(1978)6<630:PCOTIO>2.0.CO;2

Kerber, J.E., (1985). Digging for Clams: Shell Midden Analysis in New England. North Am. Archaeol., 6, 97-113. https://doi.org/10.2190/phyh-vp0r-1fm1-7eyd

Kondo, Y., (1987). Burrowing depth of infaunal bivalves - observation of living species and its relation to shell morphology. Trans. Proc. Palaeontol. Soc. Japan., 148, 306-323. https://doi.org/10.14825/prpsj1951.1987.148_306

Krantz, D.E., (1991). A chronology of Pliocene sea-level fluctuations: The U.S. middle Atlantic Coastal Plain record. Quat. Sci. Rev., 10, 163-174. https://doi.org/10.1016/02773791(91)90016-N

Krantz, D.E., (1990). Mollusk-isotope records of Plio-Pleistocene marine paleoclimate, U.S. middle Atlantic Coastal Plain. Palaios, 5, 317-335. https://doi.org/10.2307/3514888

Lisiecki, L.E., Raymo, M.E., (2005). A Pliocene-Pleistocene stack of 57 globally distributed benthic $\delta 180$ records. Paleoceanography, 20, 1-17.

https://doi.org/10.1029/2004PA001071

Lloyd, R.M., (1969). A paleoecological interpretation of the Caloosahatchee Formation, using stable isotope methods. J. Geol., 77, 1-25. https://doi.org/10.1086/627405

Loosanoff, V.L., (1937). Development of the primary gonad and sexual phases in Venus mercenaria Linnaeus. Biol. Bull., 72, 389-405. https://doi.org/10.2307/1537698

MacKenzie, C.L., Taylor, D.L., Arnold, W.S., (2001). A history of hard clamming. Dev. Aqua cult. Fish. Sci., 31, 651-673. https://doi.org/10.1016/S0167-9309(01)80042-9

Maier-Reimer, E., Mikolajewicz, U., Crowley, T., (1990). Ocean general circulation model sensitivity experiment with an open central American Isthmus. Paleoceanography, 5, 349-366. https://doi.org/10.1029/PA005i003p00349

Mannion, P. D., Upchurch, P., Benson, R. B. J., \& Goswami, A., (2014). The latitudinal biodiver 
sity gradient through deep time. Trends in Ecology and Evolution, 29, 42-50.

https://doi.org/10.1016/j.tree.2013.09.012

Masson-Delmotte, V., Schulz, M., Abe-Ouchi, A., Beer, J., (2013). Information from paleocli mate archives - Executive summary. Swiss Bull. Appl. Geol., 18, 21-24. https://doi.org/10.5169/seals-391143

Mercer, J.H., (1978). Glacial development and temperature trends in the Antarctic and in South America. In: van Zinderen Bakker, E.M. (Ed.), Antarctic Glacial History and World Paleoenvironments. Balkema, Rotterdam, pp. 73-93.

Missimer, T.M., (2001). Late Neogene geology of northwestern Lee County, Florida. In: Missimer, T.M., Scott, T.M. (Eds.) Geology and hydrology of Lee County, Florida. Florida Geol. Surv. Spec. Publ., 49, 21-34.

Moss, D.K., Ivany, L.C., Judd, E.J., Cummings, P.W., Bearden, C.E., Kim, W.J., Artruc, E.G., Driscoll, J.R., (2016). Lifespan, growth rate, and body size across latitude in marine bivalvia, with implications for phanerozoic evolution. Proc. R. Soc. B Biol. Sci., 283, 20161364. https://doi.org/10.1098/rspb.2016.1364

Moss, D.K., Ivany, L.C., Silver, R.B., Schue, J., Artruc, E.G., (2017). High-latitude settings promote extreme longevity in fossil marine bivalves. Paleobiology, 43, 365-382. https://doi.org/10.1017/pab.2017.5

Munroe, D. M., Narváez, D. A., Hennen, D., Jacobson, L., Mann, R., Hofmann, E. E., Powell, E. N., \& Klinck, J. M., (2016). Fishing and bottom water temperature as drivers of change in maximum shell length in Atlantic surfclams (Spisula solidissima). Estuar. Coast. Shelf Sci, 170, 112-122. https://doi.org/10.1016/j.ecss.2016.01.009

Narváez, D. A., Munroe, D. M., Hofmann, E. E., Klinck, J. M., Powell, E. N., Mann, R., \& Curchitser, E., (2015). Long-term dynamics in Atlantic surfclam (Spisula solidissima) populations: The role of bottom water temperature. J. Mar. Syst., 141, 136-148. https://doi.org/10.1016/j.jmarsys.2014.08.007

Norkko, J., Pilditch, C.A., Thrush, S.F., Wells, R.M.G., (2005). Effects of food availability and hypoxia on bivalves: The value of using multiple parameters to measure bivalve condition in environmental studies. Mar. Ecol. Prog. Ser., 298, 205-218. https://doi.org/10.3354/meps298205 
Oczkowski, A., Gumbley, T., Carter, B., Carmichael, R., Humphries, A., (2016). Establishing an anthropogenic nitrogen baseline using native American shell middens. Front. Mar. Sci. 3. https://doi.org/10.3389/fmars.2016.00079

Olsson, A.A., Petit, R.E., (1964). Some neogene mollusca from Florida and the Carolinas. Bull. Am. Paleontol., 47, 509-565.

Ottens, K.J., Dietl, G.P., Kelley, P.H., Stanford, S.D., (2012). A comparison of analyses of drill ing predation on fossil bivalves: Bulk- vs. taxon-specific sampling and the role of collector experience. Palaeogeogr. Palaeoclimatol. Palaeoecol., 319-320, 84-92. https://doi.org/10.1016/j.palaeo.2012.01.006

Pace, S. M., Powell, E. N., \& Mann, R., (2018). Two-hundred year record of increasing growth rates for ocean quahogs (Arctica islandica) from the northwestern Atlantic Ocean. J. Exp. Mar. Biol. Ecol., 503, 8-22. https://doi.org/10.1016/j.jembe.2018.01.010

Peck, L., Conway, L., (2000). The myth of metabolic cold adaptation: Oxygen consumption in stenothermal Antarctic bivalves. Geol. Soc. Spec. Publ., 177, 441-450. https://doi.org/10.1144/GSL.SP.2000.177.01.29

Peterson, C., (1986). Quantitative allometry of gamete production by Mercenaria mercenaria into old age. Mar. Ecol. Prog. Ser., 29, 93-97. https://doi.org/10.3354/meps029093

Peterson, C.H., (2002). Recruitment overfishing in a bivalve mollusc fishery: Hard clams (Mercenaria mercenaria) in North Carolina. Can. J. Fish. Aquat. Sci., 59, 96-104. https://doi.org/10.1139/f01-196

Peterson, C.H, Duncan, P., Summerson, H., Safrit Jr, G., (1983). A mark-recapture test of annual periodicity of internal growth band deposition in shells of hard clams, Mercenaria mercenaria, from a population along the southeastern United States. Fish. Bull., 81, 765779.

Peterson, C.H., Fegley, S.R., (1986). Seasonal allocation of resources to growth of shell, soma, and gonads in Mercenaria mercenaria. Biol. Bull., 171, 597-610.

Peterson, C.H., Summerson, H.C., Duncan, P.B., (1984). The influence of seagrass cover on population structure and individual growth rate of a suspension-feeding bivalve, Merce. 
naria mercenaria. J. Mar. Res., 42, 123-138.

https://doi.org/10.1357/002224084788506194

Powell, M.G., (2000). Morphometric characterization of a Mercenaria spp . (Bivalvia) hybrid zone: Paleontological and evolutionary implications. Analysis, 1-48.

Quitmyer, I.R., Jones, D.S., Arnold, W.S., (1997). The sclerochronology of hard clams, Mercenaria spp., from the south-eastern U.S.A.: A method of elucidating the zooarchaeological records of seasonal resource procurement and seasonality in prehistoric shell middens. J. Archaeol. Sci., 24, 825-840.

https://doi.org/10.1006/jasc.1996.0163

Raymo, M.E., Grant, B., Horowitz, M., Rau, G.H., (1996). Mid-Pliocene warmth: Stronger greenhouse and stronger conveyor. Mar. Micropaleontol., 27, 313-326. https://doi.org/10.1016/0377-8398(95)00048-8

Raymo, M.E., Ruddiman, W.F., Backman, J., Clement, B.M., Martinson, D.G., (1989). Late Pliocene variation in northern hemisphere ice sheets and North Atlantic deep water circulation. Paleoceanography 4, 413-446. https://doi.org/10.1029/PA004i004p00413

Richards, H., (1967). Stratigraphy of Atlantic Coastal Plain between Long Island and Georgia: Review. Am. Assoc. Pet. Geol. Bull., 51, 2400-2429. https://doi.org/10.1306/5d25c27b$16 \mathrm{c} 1-11 \mathrm{~d} 7-8645000102 \mathrm{c} 1865 \mathrm{~d}$

Ridgway, I.D., Richardson, C.A., (2011). Arctica islandica: The longest lived non colonial ani mal known to science. Rev. Fish Biol. Fish. 21, 297-310. https://doi.org/10.1007/s11160010-9171-9

Ridgway, I.D., Richardson, C.A., Enos, E., Ungvari, Z., Austad, S.N., Philipp, E.E.R., Csiszar, A., (2011b). New species longevity record for the northern quahog (=hard clam), Mercenaria mercenaria. J. Shellfish Res., 30, 35-38. https://doi.org/10.2983/035.030.0106

Robinson, M.M., Dowsett, H.J., Chandler, M.A., (2008). Pliocene role in assessing future cli mate impacts. Eos, 89, 501-502. https://doi.org/10.1029/2008EO490001

Ruddiman, W.F., Raymo, M., McIntyre, A., (1986). Matuyama 41,000-year cycles: North Atlan 
tic Ocean and northern hemisphere ice sheets. Earth Planet. Sci. Lett. 80, 117-129. https://doi.org/10.1016/0012-821X(86)90024-5

Saloman, C., Taylor, J.L., (1969). Age and growth of large southern quahogs from a Florida estuary. Porc. Nat. Shellfish. Assoc., 59, 46-51.

Sato-Okoshi, W., Okoshi, K., (2008). Characteristics of shell microstructure and growth analysis of the Antarctic bivalve Laternula elliptica from Lützow-Holm Bay, Antarctica. Polar Biol., 31, 131-138. https://doi.org/10.1007/s00300-007-0340-9

Saulsbury, J., Moss, D.K., Ivany, L.C., Kowalewski, M., Lindberg, D.R., Gillooly, J.F., Heim, N.A., McClain, C.R., Payne, J.L., Roopnarine, P.D., Schöne, B.R., Goodwin, D., Finnegan, S., (2019). Evaluating the influences of temperature, primary production, and evolutionary history on bivalve growth rates. Paleobiology, 45, 405-420. https://doi.org/10.1017/pab.2019.20

Savarese, M., Walker, K.J., Stingu, S., Marquardt, W.H., Thompson, V., (2016). The effects of shellfish harvesting by aboriginal inhabitants of Southwest Florida (USA) on productivity of the eastern oyster: Implications for estuarine management and restoration. Anthropocene, 16, 28-41. https://doi.org/10.1016/j.ancene.2016.10.002

Scherer, R.P., Bohaty, S.M., Dunbar, R.B., Esper, O., Flores, J.A., Gersonde, R., Harwood, D.M., Roberts, A.P., Taviani, M., (2008). Antarctic records of precession-paced insolation-driven warming during early Pleistocene Marine Isotope Stage 31. Geophys. Res. Lett., 35. https://doi.org/10.1029/2007GL032254

Schöne, B.R., Fiebig, J., Pfeiffer, M., Gleß, R., Hickson, J., Johnson, A.L.A., Dreyer, W., Oschmann, W., (2005). Climate records from a bivalved Methuselah (Arctica islandica, Mollusca; Iceland). Palaeogeogr. Palaeoclimatol. Palaeoecol., 228, 130-148. https://doi.org/10.1016/j.palaeo.2005.03.049

Slattery, J.P., Lutz, R.A., Vrijenhoek, R.C., (1993). Repeatability of correlations between heterozygosity, growth and survival in a natural population of the hard clam Mercenaria mercenaria. J. Exp. Mar. Bio. Ecol., 165, 209-224. https://doi.org/10.1016/00220981(93)90106-X

Stanley, S.M., (1988). Adaptive morphology of the shell in bivalves and gastropods. In: True man, E.R., Clarke, M.R. (Eds.), The Mollusca. Form and Function. Vol. 11. Academic Press, London, pp. 105-141. https://doi.org/10.1016/b978-0-12-751411-6.50012-6 
Stenzel, H.B., (1955). Ancestors of the quahog. SEPM J. Sediment. Res., 25, 145-145. https://doi.org/10.1306/d426990e-2b26-11d7-8648000102c1865d

Surge, D., Kelly, G., Arnold, W.S., Geiger, S.P., Goewert, A.E., Walker, K.J., (2008). Isotope sclerochronology of Mercenaria mercenaria, M. Campechiensis, and their natural hybrid form: Does genotype matter? Palaios, 23, 559-565. https://doi.org/10.2110/palo.2007.p07-056r

Surge, D., Walker, K.J., (2006). Geochemical variation in microstructural shell layers of the southern quahog (Mercenaria campechiensis): Implications for reconstructing seasonality. Palaeogeogr. Palaeoclimatol. Palaeoecol., 237, 182-190. https://doi.org/10.1016/j.palaeo.2005.11.016

Surge, D.M., Schöne, B.R., (2015). Bivalve sclerochronology. In: Rink, W.J., Thompson, J.W. (Eds.), Encyclopedia of Scientific Dating Methods. Springer pp. 108-115. https://doi.org/10.1007/978-94-007-6326-5_165-1

Tao, K., (2012). Neogene low-latitude seasonal environmental variations: Stable isotopic and trace elemental records in mollusks from the Florida platform and the Central American Isthmus. Unpublished PhD dissertation. Texas A\&M Univ., 168 pp.

Tuomey, M., Holmes, F.S., (1857). Pleiocene Fossils of South-Carolina: Polyparia, Echinoder nata and Mollusca.

Van Voorhies, W. A., (2001). Metabolism and lifespan. Exp. Gerontol., 36, 5564. https://doi.org/10.1016/S0531-5565(00)00208-4

Vladimirova, I.G., Kleimenov, S.Y., Radzinskaya, L.I., (2003). The relation of energy metabo lism and body weight in bivalves (Mollusca: Bivalvia). Biol. Bull., 30, 392-399. https://doi.org/10.1023/A:1024822225406

Walker, R.L., Heffernan, P.B., (1995). Sex ratio of the northern quahog according to age, size, and habitat in coastal waters of Georgia. Trans. Am. Fish. Soc., 124, 929-934. https://doi.org/10.1577/1548-8659(1995)124<0929:srotnq>2.3.c0;2

Walker, R.L., Tenore, K.R., (1984). The distribution and production of the hard clam, Mercenaria mercenaria, in Wassaw Sound, Georgia. Estuaries, 7, 19-27. 
https://doi.org/10.2307/1351953

Ward, L., Bailey, R., Carter, J., (1991). Pliocene and early Pleistocene stratigraphy, depositional history, and molluscan paleobiogeography of the Coastal Plain, in: The Geology of the Carolinas., pp. 274-289.

Ward, L., Blackwelder, B., (1987). Late Pliocene and early Pleistocene mollusca from the James City and Chowan River formations at the Lee Creek Mine, in: Ray, C.E. (Ed.), Geology and Paleontology of the Lee Creek Mine, North Carolina, II. Smithsonian Contributions to Paleobiology, pp. 113-283.

Ward, L.W., (1980). Stratigraphy of Eocene, Oligocene, and lower Miocene Formations; coastal plain of the Carolinas, in: Stratigraphy of Eocene, Oligocene, and Lower Miocene Formations; Coastal Plain of the Carolinas., pp. 190-210.

Ward, L.W., Blackwelder, B.W., (1980). Stratigraphic revision of upper Miocene and lower Pliocene beds of the Chesapeake Group, middle Atlantic Coastal Plain. US Geol. Surv. Bull., 1482-D, 1-61.

Willard, D.A., Cronin, T.M., Ishman, S.E., Litwin, R.J., (1993). Terrestrial and marine records of climatic and environmental changes during the Pliocene in subtropical Florida. Geology, 21, 679-682. https://doi.org/10.1130/0091-7613(1993)021<0679:TAMROC>2.3.CO;2

Winkelstern, I., Surge, D., Hudley, J., (2013). Multiproxy sclerochronological evidence for PlioPleistocene regional warmth: United States mid-Atlantic Coastal Plain. Palaios 28, 649660. https://doi.org/10.2110/palo.2013.p13-010r

Winkle, W. Van, Feng, S.Y., Haskin, H.H., (1976). Effect of temperature and salinity on exten sion of siphons by Mercenaria mercenaria. J. Fish. Res. Board Canada, 33, 1540-1546. https://doi.org/10.1139/f76-193

Zachos, J., Pagani, H., Sloan, L., Thomas, E., Billups, K., (2001). Trends, rhythms, and aberra tions in global climate $65 \mathrm{Ma}$ to present. Science, 292, 686-693. https://doi.org/10.1126/science.1059412 